Discussion

Papers

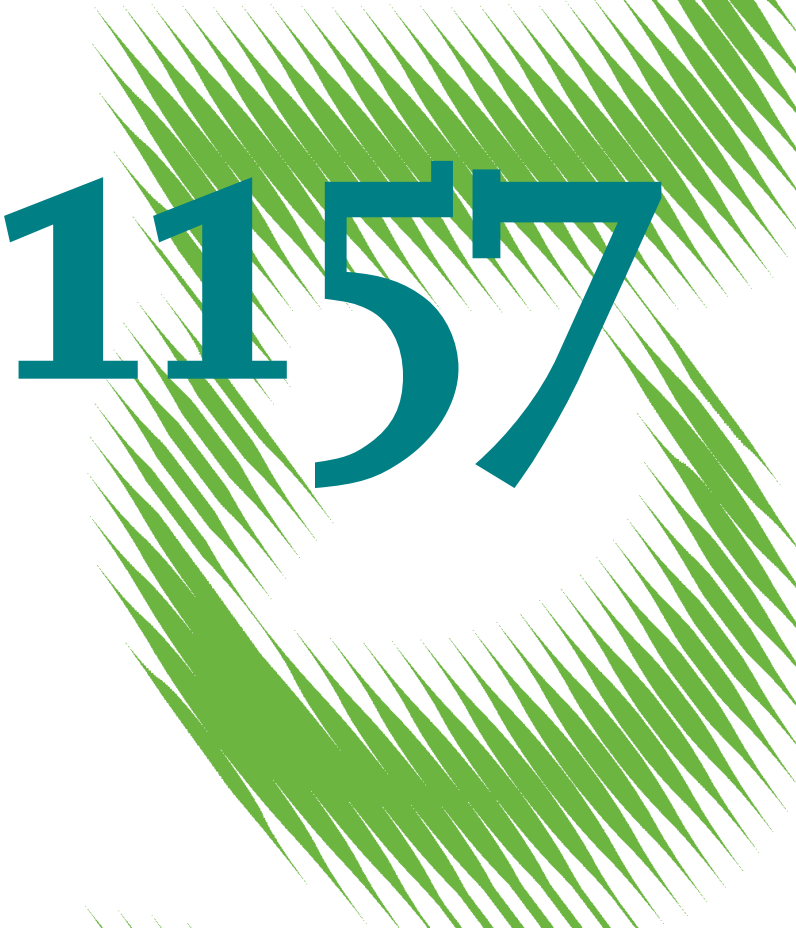

A Critique and Reframing of Personality in Labour Market Theory

Locus of Control and Labour Market Outcomes 
Opinions expressed in this paper are those of the author(s) and do not necessarily reflect views of the institute.

IMPRESSUM

(C) DIW Berlin, 2011

DIW Berlin

German Institute for Economic Research

Mohrenstr. 58

10117 Berlin

Tel. $+49(30) 89789-0$

Fax +49 (30) $89789-200$

http://www.diw.de

ISSN print edition $1433-0210$

ISSN electronic edition 1619-4535

Papers can be downloaded free of charge from the DIW Berlin website:

http://www.diw.de/discussionpapers

Discussion Papers of DIW Berlin are indexed in RePEc and SSRN:

http://ideas.repec.org/s/diw/diwwpp.html

http://www.ssrn.com/link/DIW-Berlin-German-Inst-Econ-Res.html 


\title{
A Critique and Reframing of Personality in Labour Market Theory Locus of Control and Labour Market Outcomes
}

\author{
Eileen Trzcinski \\ Wayne State University \\ School of Social Work \\ Detroit, MI \\ USA \\ <e.trzcinski@wayne.edu>
}

\section{Elke Holst}

German Institute for Economic Research

Berlin, Germany

<eholst@diw.de>

\begin{abstract}
This article critically examines the theoretical arguments that underlie the literature linking personality traits to economic outcomes and provides empirical evidence indicating that labour market outcomes influence personality outcomes. Based on data from the German Socio-Economic Panel, we investigated the extent to which gender differences occur in the processes by which highly positive and negative labour market outcomes are determined and in the processes underlying the development of one particular aspect of personality, locus of control. Gender differences were more pronounced in the results for years in managerial/ leadership positions than for locus of control. Negative labour market states were also marked by gender differences. We conclude by arguing that an explicitly value-laden analysis of the rewards associated with personality within the labour market could expose areas where the gendered nature of rewards by personality serves to perpetuate power relationships within the labour market.
\end{abstract}




\section{INTRODUCTION}

The purpose of this article is threefold. First, we seek to critically examine the theoretical arguments that underlie the literature linking personality traits to economic outcomes. Second, we provide additional empirical evidence that shows that labour market outcomes do indeed influence personality outcomes and that this endogeneity has broad societal impacts for a wide range of outcomes. This evidence adds to the extensive theoretical and empirical work produced by feminist economists that strongly and consistently shows that the labour market is not the neutral institution that it is presumed to be within traditional neoclassical theory. Third, we argue that the personality traits are more useful in highlighting how gender functions as a social construct within the labour market than as additional explanatory variables that serve to reduce the unexplained gender differences in labour market outcomes.

Economists have increasingly begun to incorporate personality constructs into labour market analyses. Together with a number of other economists, James Heckman has, for example, recently published a series of articles explicitly advocating for the inclusion of such variables in order to enhance our understanding of labour market processes ${ }^{\mathrm{i}}$, thereby signalling that such articles are now welcomed by traditional mainstream economic journals. The stated purpose of most of this research is to highlight how personality differences between men and women (or between other groups occupying different labour market positions) lead to different economic outcomes.

In order to contribute to this literature, this article jointly examines the extent to which gender differences and similarities are observed in the processes by which highly positive and negative labour market outcomes are determined versus the processes underlying the development of one particular aspect of personality, locus of control. This construct measures the extent to which individuals believe they have control over the circumstances that affect their lives. At one extreme, individuals who are fatalistic believe that events are completely outside of their personal control; at the opposite extreme, individuals believe they have the complete and total ability to influence what occurs in their lives through their own actions. Locus of control is investigated in this study for a number of reasons. It has been shown to have strong associations with a range of psychological and sociological outcomes. Locus of control is also an important predictor of long-term educational and labour market outcomes. 
As noted by Melissa Osborne-Groves (2005), locus of control is perhaps the most widely used personality variable in economic and sociological research. It is a factor that economists have identified as an important predictor of labour market outcomes via both direct and indirect pathways. It has also been found to be a personality construct that is not fixed, but is influenced by socio-economic conditions, a range of environmental conditions and demographic variables as well as by less malleable factors, such as stable personality traits. As discussed below, most of the economic literature that investigates the role of locus of control within the labour market has, however, treated adult locus of control as exogenous to labour market outcomes. Thus if we can demonstrate the locus of control is endogenous within the labour market, we have grounds to assert that the labour market is not a neutral institution existing separately from the rest of society. The positive labour market state that we examine is years in a managerial position; the negative outcome is the number of years where unemployment was experienced.

The rationale for focusing on the most favourable and the least favourable employment outcomes stems from the theoretical importance of these two labour market states in affecting not only individual economic outcomes but also broader societal and labour market outcomes, such as influence within the workplace and the degree of social exclusion. In western market economies, those with relatively greater influence within the workplace also tend to exert relatively greater influence within the society as a whole. Unemployment, particularly long term unemployment, is associated with a wide range of negative psychological and health outcomes in addition to its contribution to poverty and social exclusion for unemployed individuals, their families, and their communities. Furthermore gender differences exist in the extent to which women and men occupy positions of leadership in the labour market and unemployment, but most of the existing literature linking locus of control and these two employment outcomes tends to focus exclusively on one of these states, but not both. Thus a study that simultaneously examines the link between locus of control and these two labour market outcomes offers the possibility to understand more deeply and more comprehensively how the dynamics of gender operate within the labour market as a whole. 


\section{Critique of Economic Theories on Economic Outcomes and Personality Traits}

Economic theories linking personality constructs to economic outcomes can be classified into three major theories:

1. Utility theory expanded to include the broad personality concept of "identity"

2. Standard human capital theory

3. Principal agent theories.

The dynamics within each of the models are based on the actions of individuals; the labour market itself remains neutral as a societal institution in terms of its role in creating, reproducing, and re-enforcing any inequities. Within these theories, explanations concerning the processes surrounding the link between specific personality traits and specific outcomes tend to be ad hoc. They are then used to justify the claim that differences in economic outcomes result in part from group differences in the personality traits examined.

Each theory takes as given an unequal distribution of economic outcomes and then seeks to provide insight into how the individual endowments, skills, preferences, and / or constraints are rewarded within a labour market that itself plays no direct role in creating and reproducing disparities by race, gender, and/or class. The labour market responds to these differences in skills, preferences and constraints but itself has no function in creating or reproducing these differences. These economic theories do not invoke the sociological concept of "gendered" organizations to explain how personality traits and economic outcomes are linked. The labour market itself is not culpable in generating inequities, although the behaviour of individual agents, primarily as employees or co-workers may result in the perpetuation of negative outcomes. Uncertainty and lack of perfect information are accommodated by such theories; power differentials are not. Power differentials can only operate outside of the labour market itself-perhaps by allowing the creation of schools that reproduce a docile workforce; perhaps by creating differential identities between men and women. Even in these cases, however, those who suffer under the consequences of these power imbalances are assumed to be equally responsible and culpable for the maintenance of inequities that exist across gender, race, and class. 


\section{Economics and Identity}

Akerlof and Kranton (2000) developed a model in which they incorporated identity into a general model of behaviour. They then used this model to attempt to demonstrate how identity as an aspect of personality influences economic outcomes. At the very outset of the article, they provide the basic motivation by claiming that their theory can resolve apparent contradictions in the actions of specific actors, such as “why some women oppose ‘women’s rights' (p. 715).” Central to their theory is the pre-existence of social difference:

Our identity model begins with social difference. Gender, a universally familiar aspect of identity, illustrates. There are two abstract social categories, “man” and “woman”, following the behavioural prescriptions for one’s gender affirms one’s self-image, or identity, as a “man” or "woman” (...). Violating the prescriptions evokes anxiety and discomfort in oneself and in others. Gender identity, then, changes the 'payoffs' from different actions (Akerlof and Kranton, 2000, pp. 716-717).

Such identities can then serve to explain why some individuals engage in behaviour that Akerlof and Kranton label as detrimental, maladaptive or even self-destructive. Also noteworthy in their assumptions is that some people, but not all, have the right to choose their identity: “...choice of identity may be the most important 'economic' decision people make. Individuals may - more or less consciously choose who they want to be (p. 717).” They do note, however, that limits on this choice could indeed be the most important determinant of an individual's well-being.

Their model lacks mechanisms for the creation of power differentials; power differentials exist, but as necessary pre-conditions to produce theoretical results. In developing a formal mathematical model, they state:

Categories may also have higher or lower social status. We use the word identity to describe both a person's self-image as well as her assigned categories. ...

Gender identity could be formalized as follows. There is a set of categories $\mathbf{C}$, "man” and “woman”, where men have higher social status than women. (Akerlof and Kranton, 2000, p. 71). 
Identity is then used to provide justification for some of the most egregious behaviour experienced by some women in the labour market. The authors describe the case of a woman working in a coal plant; she is physically assaulted by her male co-workers by being picked up, tossed back and forth, with an attempt to 'jokingly’ push her onto the coal conveyer belt. In another case, a woman was denied routine assistance that the male workers would have provided to a new male co-worker. After describing these incidents, the authors then cite survey results where respondents indicated that men respond in such negative and destructive ways when women occupy traditionally male jobs because the men feel less masculine. Akerlof and Kranton proceed to attribute such behaviour to ‘identity’ and contend that their attribution fits standard beliefs within society at large.

Furthermore, the authors argue that if someone with a given identity engages in activity that contradicts his / her identity, then "she would lose her ...identity. This loss in identity entails a reduction in utility of $I_{s}$, where the subscript $s$ stands for "self” "and the 'I' for identity (p. 727-728). The implications of such a theory are profound. If women, as an abstract group, act to maintain their identity or to thwart attempts by others who threaten their identity, they simultaneously act to maintain the economic disadvantage under which they suffer relative to the other abstract group, "men”. However, when men act individually or collectively to maintain their own identity or act against those who threaten their identity, such as in these actions against women who work in coal mines, the men continue to maintain their economic advantage. Thus psychological constructs, such as identity, are easily incorporated into a model where women are seen as acting rationally in terms of overall utility maximization when they balance their identity interests against their economic interests. In the case of women, this balance requires a trade-up between the two sets of arguments in their utility function. Men also balance their economic and identity interests, but as a group they gain economically when they act in such a manner, whereas women lose.

Men and women may operate within or outside of the labour market to maintain their respective identities, but the labour market itself simply responds to these actions as a passive bystander. Akerlof and Kranton (2000) claim that their model captures the 'auras of gender' that have pervaded the labour market because occupations are associated with the social categories "man” and "woman” and “individual payoffs from different types of work reflect these differences (p. 732).” Firms must react 
to the identity preferences of workers, otherwise they will suffer losses. A firm will suffer productivity losses, according to Akerlof and Kranton, if they change gender-job associations. Hence the firm is likely to “create a 'woman’s job' alongside the 'man's job', rather than render the whole task gender neutral, when a new job description can piggyback on existing notions of male and female” (p. 733). Firms do indeed react to the needs of employees to maintain identity within their model, but the firms are forced to react to adjust for market forces that are constrained by identitypreferences of workers. Women lose, men gain, and firms are neutral in responding to the psychological needs presented by their employees. This theory provides no room for firms to benefit directly from the economic outcomes produced and generated by occupational segregation or by the behaviour of the privileged group that seeks to avoid threats to its identity. Firms act to minimize losses; that they could directly gain from creating and maintaining such an arrangement is not allowed in this theory. Akerlof and Kranton do not directly test the implications of theory with data, but instead rely throughout on a collection of anecdotal evidence that provide support for the basic tenets of their theory. Not surprisingly, this anecdotal evidence excludes evidence that contradicts their theory. In their theory, the maintenance of identity could result in bullying activities both within and outside of the workplace. Firms, however, gain no direct benefits from creating or encouraging such behavior. Therefore it is unclear how their analysis would accommodate the fact that within the United States, opposition to state-level Healthy Workplace Bills that would make bullying illegal has come primarily from state chapters of the Chamber of Commerce and from management-side employment lawyers (David C. Yamada, 2009) ${ }^{\mathrm{ii}}$.

Within the United States, the business committee was one of the most vocal sectors in expressing opposition to the 1980 inclusion of sexual harassment as part of U.S. Equal Employment Opportunity Commission’s (EEOC) antidiscrimination policy in 1980 (Jones, 2008). ${ }^{\text {iii }}$ Had Akerlof and Kranton attempted to incorporate such evidence into their model of the link between identity and utility, the role played by the agency of individual women seeking to maintain their identity would clearly be diminished relative to the role that might be played by employers. In order to account for such evidence regarding historical opposition of the business committee to laws against sexual harassment and contemporary opposition to laws directed at workplace bullying, the potential 
advantages to employers of maintaining identity-based inequities would need to be recognized rather than ignored.

\section{Human Capital Theory and Personality}

As long as women as a group display some group differences in basic personality traits, it is easy to argue that these differences will result in labour market outcomes that favour men as a group over women as a group by arguing that personality traits are linked to productivity differences. According to Gerrit Mueller and Erik Plug (2006), the standard economic approach views personality as a bundle of productive attributes valued in the labour market:

Earnings follow, as usual, from the kind and amount of traits possessed, and the return that each trait receives in the market. We thereby implicitly assume that personality affects behaviour. This view closely corresponds to that of trait theorists who believe that personality traits constitute basic determining tendencies. ... Differences in personality can lead to differences in pay via three channels: differences in skills, differences in preferences, and a discriminating labour market. ... Since job performance is closely related to the economist's notion of productive output, we may associate these personality effects directly with higher earnings. (pp. $4-5)$.

They also argue that:

Any group differences in personality traits between men and women will translate into gender differences in earnings either directly, through productivity differences or indirectly through occupational segregation (p. 5).

Similar arguments are advanced by other researchers working in this tradition (Cobb-Clark and Tan, 2011; Nils Braakmann, 2009; Osborne, 2005). If women as a group tend to score higher on the Big Five personality trait of neuroticism, then women as a group must earn less and occupy less favourable positions in the labour market because neuroticism is surely linked to lower productivity. Hence Mueller and Plug explicitly argue that they expect the agreeableness and neuroticism dimensions of the Big Five personality traits to be of importance because the literature indicates that agreeableness and neuroticism are the two traits most consistently showing the largest gender differences. Lee Borghans et al. (2008) also assert the following regarding neuroticism: 
With increases in, for example, neuroticism, shadow prices of activities intensive in that trait will increase. Labour earnings will tend to decrease. In the price-elastic case, consumers will tend to substitute away from activities intensive in the trait and the demand for inputs will decrease. In the inelastic case, input demands will increase as agents substitute goods and energy inputs into the activities that are inelastically demanded (p. 1026).

Conversely, other traits, such as conscientiousness, can be productivity enhancing:

Consider an increase in conscientiousness. This will likely increase earnings and will enhance productivity in some tasks intensive in conscientiousness and activities based on those tasks more than other tasks and activities. The increased income will support more of all activities. The differential shift in productivity across tasks and activities will reduce the prices of activities that are more intensive in the use of conscientiousness. If the demands for those activities are price elastic compared to the demands for the less conscientiousness-intensive activities, the demand for the inputs used in those activities will increase. If the demands are relatively inelastic, the demands will decrease because of the greater productivity for the inputs (p. 1026). Despite the apparent intuitive appeal of labelling "neuroticism” as an inherently productivityreducing trait, one could just as easily argue the converse, were it necessary to do so in order to justify personality-based gender differences in earnings that favoured the preferred group, that is, men. Jennifer Wolak and George Marcus (2007) have presented empirical evidence dealing with the relationship between personality traits and the practice of citizenship. Although the overall size of the observed relationship was not strong, they found that increases in neuroticism were associated with a heightened desire to learn more about a particular policy and a heightened desire to engage in political action. Based on past research, they further argued that anxiety is often associated with the need to take action, to gather more information and to rely on "deliberate strategies rather than continued reliance on habitual responses (p. 173).” In their conceptual framework, some situations are well served by a reliance on previously learned routines, but in other situations, greater attention and consideration are needed. Neuroticism could therefore theoretically lead to productivity-enhancing as well as productivity-diminishing effects. Were neuroticism considered a male trait, it is also likely that its name would not immediately convey that it is trait with negative repercussions. Perhaps it might be 
labelled emotional responsiveness, indicating that those with higher scores display greater sensitivity to environmental stimuli and thus act more quickly and effectively because their anxiety signals that action needs to be taken to resolve a problematic situation.

For traits where men tend to score more highly, such as willingness to take risks, the reverse of the neuroticism argument is invoked. If men as a group tend to be more risk loving than women, then they will, of course, reap rewards for the differences in group means on this "productivity-enhancing” trait. These arguments cannot be countered because if associations are found between these traits and labour market outcomes, then the labour market is simply rewarding real differences in skills and preferences with real differences in wages and occupational status. Obvious negative societal repressions of high tolerances towards risk are not visible within these theories, such as the consequences of building nuclear power plants in areas known to be subject to earthquakes and tsunami threats. These difficulties are discretely never mentioned in the neoclassical economic literature that ties risk taking behaviour to higher wages. Also absent in the economic literature linking risk and wages is the role of legislation that creates a system of economic conditions that reward risky behaviour and that protect the risk lovers from the consequences of their behaviour ${ }^{\text {iv }}$.

This theory also deals with how personality traits can lead to differences in preferences. Within this line of reasoning, theorists rely on specific examples of the processes by which differences in preferences lead to different economic rewards for those with different personality traits even in the absence of evidence that the trait is productivity enhancing. Not surprisingly, these ad hoc theoretical arguments usually work to the advantage of men over women. Under the contention that personality produces differences in preferences, one has no need to make the rather questionable argument that "agreeableness” is a productivity diminishing trait to show why "more agreeable” women fare worse than "more antagonistic" men. Instead agreeableness is linked to preferences regarding negotiation. For example, Linda Babcock and Sara Laschever (2003) have argued that traits can affect earnings indirectly if a greater tendency to compromise affects the results of wage negotiations. Men who are more antagonistic than women enjoy bargaining and negotiating more than women do. Men’s preference for bargaining results in their obtaining higher wages and more promotions because it suits their more antagonistic personalities and increases their utility. Women whose agreeable personalities 
lead them to have preferences where they shy away from hard bargaining and tough negotiating pay the price of lower wages relative to men (Mueller and Plug, 2006). Just as in the identity model of Akerlof and Kranton, women must balance competing and conflicting arguments in their utility function, trading economic benefits for psychological comfort as they avoid the displeasure associated with driving a hard bargain. Men face no such dilemma and their dual preferences for bargaining and higher economic returns re-enforce each other.

In a separate line of argument, however, agreeableness has been held to work to the advantage of women in terms of increasing the opportunities available to women within the economy. As the economy has moved to more service-oriented jobs, the prospects for employment of women have increased, which is viewed as a direct result of the labour market offering jobs requiring greater levels of sociability (Borghans et al., 2005). This change is also argued to have been detrimental to the labour market situation of African Americans within the United States and to immigrants in Germany and England. Borghans et al. (2005) do not directly argue that African Americans are less sociable than Whites. Instead they argue that "racial and ethnic minorities may be less effective in interpersonal interactions with members of a majority culture (p. 23)”, a critique of the power dynamics and societal inequities that allow such a statement to have meaning in the real world is left entirely to the reader. When researchers, such as Borghans et al. find such results and do not imbed their findings in a theory that deals with the underlying power dynamics, the processes that create the inequities remain unexplored—personality differences, in this case degree of sociability, are responsible for the ability of different groups to respond to changing economic circumstances. For women, these characteristics are in demand and hence their labour market situation has improved ${ }^{\mathrm{v}}$.

\section{Existence, source and consequences of personality differences between men and women.}

Part of the motivation for including personality constructs in human capital models of wage determination and occupational attainment stems from the inadequacy of other variables in accounting for gender differences in economic outcomes. Within these models, personality traits can serve to chip away at the "unobserved heterogeneity" that is said to account for the unexplained differences in wages and other economic outcomes that are observed between men and women. Following what could be viewed as the required script in the human capital literature, discrimination is always 
mentioned as a possibility for these unexplained differences, with the mandatory caveat that "it is difficult to separate empirically the differences in pay that are due to discrimination from differences in unobserved preferences and productive traits (Mueller and Plug, 2006).” But economists are clearly uncomfortable with discrimination as a long-term explanation for gender differences, hence the search for the missing variable(s) that could show that Gary Becker (1971) indeed was correct in predicting the eventual disappearance of discrimination under assumptions of profit maximizing behaviour on the part of firms.

Under human capital theory, necessary prerequisites for personality traits to play a role in reducing this unobserved heterogeneity are (1) that systematic differences do exist between men and women; (2) that these differences in personality lead to differences in economic outcomes and (3) that these personality differences are not endogenous with respect to labour market outcomes. Research does consistently indicate that personality differences do exist between men and women in the aggregate. These generalizations tend to dissolve as meaningful representations of reality when examined more closely. Virtually every study does find some degree of statistically significant difference on at least some traits between men and women, but where the differences are observed differ from study to study (see Marianne Bertrand, 2010 for a review of these results). Even where the differences are more consistent, such as risk aversion, the meaning and correspondence between the measured trait and underlying source of these differences are contested—a debate that we discuss below.

Although gender differences are often assumed to exist in terms of risk-taking behaviour, the evidence regarding gender differences is complex and nuanced. Numerous studies based on both selfassessments of the willingness to take risks and on experimental studies have concluded that women have a greater aversion to risk than men. In a critical review of this literature, Rachel Croson and Uri Gneezy (2009) found that the majority of studies did support the hypotheses that women are more risk adverse than men. They concluded, however, that the experiments described in the literature usually failed to account for interactions between the experimental context and the gender of the participant. A second criticism was that "journals are more likely to publish paper that find a gender difference than 
papers that do not" and that "this publication bias may cause researchers to invest more effort into finding differences than to finding no difference (Croson and Gneezy, 2009: 468)”.

Research conducted by Sabina Littmann-Wernli and Renate Schubert (2001) confirmed the conclusions reached by Croson and Gneezy. Based on a set of comprehensive gender-comparative experiments, Littmann-Wernli \& Schubert (2001) concluded that it was incorrect to assert that women are more risk-averse. Instead their results indicated that "the 'framing' of information is of importance" in determining the extent and nature of differences in risk-taking behaviour for women and men (Littmann-Wernli and Schubert, 2001: 145). In context-related decision problems, their studies indicated that there were no significant differences between men and women in willingness to take risks. In other cases, however, such as abstract game situations, women were more willing to take risks when it came to a losing game but more risk averse when it came to a winning game. In addition, information about probabilities of success had different effects on the risk behaviour of women and men. Definitions of what constitutes risk taking behaviour also favour men over women in terms of what is labelled as risk taking behaviour. Many women undertake substantial short and long-term economic risks when they choose to become full-time homeworkers or to work part-time; yet such behaviour is generally not taken as evidence of a high tolerance towards economic risk.

Although most studies find that women are less emotionally stable than men, that is more neurotic, Deborah Cobb-Clark and Michelle Tan (2011) found that men were more neurotic than women based on data from the Australian Household Income and Labour Dynamics survey. Thus even for a trait that is generally assumed to work to the disadvantage of women, the data are not consistent in terms of gender differences in the underlying distribution of the trait in representative national samples. They also found that men are more open to experience than women, a finding that contradicts many other studies on this personality dimension.

Not only are studies inconsistent in terms of where gender differences exist, the observed returns to personality also vary by gender both within and across different studies. In research linking the Big Five personality traits with labour market outcomes, for example, successful leaders have tended to exhibit high scores in the dimensions extraversion, conscientiousness and emotional stability (= low neuroticism value) and low scores in the agreeableness dimension (Murray Barrick \& Michael 
Mount, 1991, 2005; Murray Barrick, Michael Mount, and Timothy A. Judge, 2001, J.W. John Boudreau, Wendy R. Boswell, and Timothy A. Judge, 2001; Adrian Furnham, John Crump, and Josh Whelan, 1997; Ralph Piedmont and Harold Weinstein, 1994). A highly positive link with job performance across all professional groups has also been observed for the conscientiousness dimension in most studies (Murray Barrick and Michael Mount, 1991; Robert P. Tett, Douglas N. Jackson, and Mitchell Rothstein 1991; Jesus F. Salgado, 1997). In their study of leadership ability in 160 leaders, Adrian Furnham, John Crump and Josh Whelan (1997) found strong positive influence on leadership ability for the conscientiousness and extraversion dimensions. In contrast, however, Boudreau et al. (2001) studied the link between the Big Five and the career success of leaders in the US and Europe and did not find conscientiousness to be a predictor of career success. Instead they found a positive link between extraversion and a negative link between neuroticism and intrinsic career success.

In a longitudinal study, Mueller and Plug (2006) investigated how the Big Five personality traits influenced wages. The study indicated that men with low scores in the agreeableness dimension and high scores in the openness to experience and emotional stability dimensions earned more than others. In these results, openness to experience had the greatest positive influence on wages, while extraversion and conscientiousness had no influence for men. However, women achieved a wage premium if they had high scores in the conscientiousness and openness to experience dimensions. Thus while research has routinely established strong links between the Big Five personality traits and success in the labour market, not all studies find consistency in which of the traits affect outcomes and in the nature of these differences for women and men.

Cobb-Clark and Tan (2011) also found substantial gender differences in the associations between noncognitive skills, occupational attainment, and relative wages. Their results suggested that men's and women's noncognitive skills have a substantial effect on their occupational attainment, but the nature of this relationship varies by gender. They found major gender differences in the links between occupation attainment and locus of control. In their study, men’s occupational attainment was linked to their locus of control, but no association was observed for women. Specifically, men who believed that much of what happens in life was outside their control were $29.5 \%$ less likely to be 
observed working as managers. The authors argued that those with a more internal locus of control were better able to take on the roles required for direction organisations and supervising staff. No explanation was offered, however, why the same process was not observed for women. Samuel Bowles, Herbert Gintis and Melissa Osborne (2001) also reported gender differences in how personality traits affected economic outcomes.

Source of differences. Most of the literature focusing on differences in personality traits and labour market consequences deals with human capital investments in children and youth. Parental and societal investments are considered the most important contributors to these differences, with low levels of investments resulting in negative personality trait outcomes that in turn contribute to less favourable labour market outcomes, indirectly through lower levels of investment in education and directly through the lower economic returns for the productivity diminishing bundle of personality traits possessed by these individuals. The extensive work produced by Heckman and his colleagues and by Bowles and Gintis represent important contributions to this line of research ${ }^{\mathrm{vi}}$. This research is, however, far more applicable to differences in personality traits by class and race, then it is to differences in personality traits observed by gender. This body of work does not address why gender differences are present in personality traits because these differences cannot be tied empirically to differential levels of investment in the countries under investigation. For example in an article entitled "Formulating, Identifying, and Estimating the Technology of Cognitive and Noncognitive Skill Formation” authored by Flavio Cunha and James J. Heckman (2006), the word “gender” does not even appear once in the text, which seems remarkable given the extent to which labour economists, including Cunha and Heckman, contend that personality differences are driven by forces outside the labour market itself and that personality is largely shaped during the periods of childhood and youth. To the extent that differences do exist in personality traits prior to labour market entry, it is noted by these researchers that these differences tend to favour girls rather than boys in terms of levels of schooling attained, grades achieved, and avoidance of anti-social behaviour with negative human capital consequences (Bertrand, 2010).

Although differential parental and societal investments are not considered as important in producing personality differences by gender, these theories allow for the re-introduction of biological 
and genetic differences between men and women to enter the void left by the long-term declining importance of gender differences in strength and speed as factors explaining productivity differences between men and women. The extent to which such arguments are voiced can be seen in titles such as The Genetics of Economic Risk Preferences (Michael Zyphur et al., 2009). Zyphur et al. state that a 'genetically oriented approach to understanding the underlying causes of risk preferences has the potential to bear significant fruits in the study of human decision-making (p. 375).” In Do Genes Contribute to the Gender Gap, Peter Hatemi, Sarah Medland and Lindon Eaves (2009), began their article with the assertion that "preferences are biologically influenced (2009, p. 262).” Although the authors do point out that "genetic influence is no more deterministic than social influence”, the attention to genetic differences between men and women in a world where men as a group have economic advantage over women as a group can easily lead to the use of such differences to justify existing inequities. Many of the economists working within the human capital tradition cite the results obtained in numerous twin studies on the heritably of personality traits, such as Braakmann (2009), who claims that twin studies indicate that between 40 to 60 percent of the variation in personality traits are due to genetic factors and hence are considered pre-determined with respect to labour market outcomes. They fail, however, to cite any literature that questions the methodology and results of these kinds of studies (see Jay Joseph, 2002, for a critique of the twin studies and Rebecca Jordan-Young, 2010, for a critique of the brain studies emphasizing inherent gender differences).

\section{Principal Agent Models under Uncertainty and Imperfect Information}

The final set of models that tie personality to labour market outcomes are the principal agent models that integrate uncertainty and imperfect information into models of labour market outcomes. These models developed primarily by Samuel Bowles and Herbert Gintis (2002) offer little insight into why differential rewards to personality exist by gender. These approaches are more useful for explaining differences that exist by class and draw on the early and more recent work of Bowles and Gintis (1976, 2001) in terms of the relationship between different types of schooling and personality development. Although they contend that their work deals with the persistence of inequality through the transmission of personality traits from parents to children, how this inequality is inherited by gender is unexplained. In fact, their 2002 article contains no reference to gender as an essential 
element in the transmission of inequality; the words "gender" and "female" do not appear even once in this article. Their models result in economic penalties for those with traits, such high discount rates, high degrees of fatalism, and low levels of conscientiousness, that are presumed to make monitoring difficult or to undermine the desire of the worker to deliver adequate effort. They argue that it is impossible to specify all dimensions of the employee-employer relationship in terms of a contract that would be enforceable by the courts. This results in an agreement where personality traits emerge as important predictors of labour market outcomes. The process by which these traits are penalized in the labour market is explained as follows:

...the actual terms of the exchange are influenced by the degree of trust, honesty, hard work and other dispositions of the parties to the exchange. For example, a very present-oriented employee will not value the employer's promise of continued employment in the future, conditional on hard work now. Instead, such an employee will require a higher wage to motivate hard work in the present and, therefore, is less likely to be employed. As another example, fatalistic workers who believe that the probability of job termination is unaffected by their own actions will be costly to motivate under this type of labor contract (Bowles and Gintis, 2002, p. 13).

\section{MODEL AND THEORECTICAL JUSTIFICATION FOR THE EXPLANATORY}

\section{VARIABLES}

Within our model, we hypothesize that gender differences will be observed both in the processes that influence employment outcomes and in the processes that influence the level of locus of control, but that the observed differences will be greater for labour market outcomes than for locus of control. This hypothesis is based on the premise that individuals have relatively little control over institutional factors affecting labour market outcomes and that these institutional factors operate differently for women and for men. We hypothesize, however, the development of differences in locus of control will demonstrate less pronounced differences by gender because these processes are more internal psychological processes that are likely to differ less between men and women than do the gendered conditions that create differential access to positive and negative labour market events. 
We estimated a three equation simultaneous equation model with data from the German SocioEconomic Panel (SOEP) where locus of control measured in 2005, total number of years with unemployment from 2001-2005, and total number of years in high level managerial/leadership positions from 2001-2005 were endogenous variables. Exogenous variables included locus of control measured in 1999, the Big Five personality traits, a measure of risk taking in career, and a set of demographic variables. Stata Version 11 was used to estimate the three equation simulation model. Three stage linear least squares maximum likelihood estimation was used to fit the model, which is considered an efficient estimation technique for a three equation set of structural equations (David A. Belsley, 1988). We also estimated a second model where the dependent variable was change in the locus of control from 1999 to 2005, which included changes in the level of the demographic and human capital variables reported from 2001 to 2005. A structural equation model investigating the linkages between locus of control in 1999, years in management and years in unemployment, and level of locus of control in 2005 was also estimated. The results of this model, which was estimated with EQS Version 6, were identical to the results presented below, indicating that the basic results are robust across three different estimation techniques. The results of the structural equation model are available from the authors upon request.

The following discussion provides the rationale for the selection of the endogenous variables—locus of control, years with unemployment and years in management—in the three equation simultaneous equation model.

\section{Locus of Control}

For decades, researchers have examined the links between locus of control and educational and labour market outcomes. This research has established strong links between internal locus of control and positive educational and labour market outcomes. Most of this research has not, however, explicitly examined gender differences in terms of how labour market outcomes influence reported levels of locus of control. The direction of the examined relationship has primarily focused on how locus of control influences labour market outcomes, but not on the influence of labour market outcomes, particularly highly favourable labour market outcomes, on the locus of control. Several meta-analyses have examined links between locus of control and different aspects of success in the 
workplace. In a meta-analysis conducted by Timothy Judge and Joyce Bono (2001), locus of control was strongly correlated with both job performance and job satisfaction. In a second meta-analysis conducted by Thomas Ng, Kelly Sorensen and Lillian Eby (2006), locus of control was related to a variety of employee attitudes, such as job satisfaction and commitment as well as to employee behaviours, such as job performance and attendance. A third meta-analysis conducted by Thomas Ng et al. (2005) found that locus of control was weakly related to salary, not related to promotions, and strongly related to job satisfaction. Recent work that examined this link includes James Heckman, Jora Stixrud, and Sergio Urzua (2006), who found that noncognitive skills, including a measure of locus of control, strongly influenced schooling decisions, employment, work experiences, and choice of occupation; Timothy Judge and Charlice Hurst (2007), who found that core self-evaluations which include locus of control as one dimension predicted both economic success in the short and long run; and Melissa Groves (2005), who found that higher levels of internal control were associated with higher wages for women.

In addition to its impact on educational and labour market outcomes, locus of control also influences outcomes in a number of other dimensions. The wide range of areas where locus of control plays a role provides a strong rationale for including locus of control within our study as both an endogenous and explanatory variable. Previous research has indicated that locus of control is an important variable in predicting life satisfaction, health behaviours, and patterns of adjustment after stressful events. External locus of control has been found to be associated with many different negative outcomes, including adjustment patterns and depression following divorce (Lisa Hill \& Jeanne Hilton, 1999, Helen Barnet, 1990) ; the level of work-family conflict (Noraini Noor, 2002); the risk of child abuse (Sharon A. Stringer and Annette M. la Greca, 1985) and suicide ideation (R. Vilhjalmsson, G. Krisjansdottir, and E. Sveinbjarnardottir (1998). Internal locus of control has likewise been shown to be associated with positive outcomes, such as the quality of the home environment provided by mothers (Elizabeth Menaghan and Toby Parcel, 1991) and level of engagement in positive family health behaviours (Marilyn Ford-Gilboe, 1997). A consistent finding of the literature on subjective life satisfaction is the positive association between internal locus of control and measures of subjective life satisfaction and subjective well-being (see Christopher Peterson, 2003, for an extensive review of the 
literature). Bruce Heady (2008) also found an internal locus of control predicted positive changes in subjective well-being over time.

\section{Unemployment}

We focus on years in unemployment because of the well-established negative implications of unemployment, particularly long-term unemployment on social, economic, and psychological wellbeing. Negative psychological, mental health and economic consequences for women and men who have experienced unemployment have been well-documented in the literature (see Signe Andersen, 2009; Kenneth Cole, Anne Daly, and Anita Mak, 2009; Bruno Frey and Alois Stutzer, 2002; Ed Diener et al. 1999; Andrew Clark and Andrew Oswald,1994; Liliana Winkelmann and Rainer Winkelmann, 1998; Cynthia Murray, Lan Gien, \& Shirley Solberg, 2003). Observed negative effects of unemployment tend to be more severe for men than for women (Lucia Artazcoz et al., 2004, Clifford Broman et al., 1995). One exception is the observed effect of unemployment on locus of control. Arthur Goldsmith, Jonathan Veum \& William Darity (1996) found that unemployment and joblessness negatively influenced locus of control for young women, but not young men.

\section{Women in Leadership Positions}

We focus on years in leadership positions because the extent to which women occupy leadership positions has strong implications at both the individual and societal level. In addition, as discussed above, personality differences and differences in preferences have been held to be responsible for the under representation of women in such positions. The lack of women in management strongly suggests that optimal levels of social justice are absent; that women are not being allowed to develop and/or fully use their full range of innate capabilities and that the labour market is not achieving optimal outcomes in regards to the total pool of talent available within the economy. Hence it is important to understand why and in what manner personality traits may be used a mechanism and / or excuse to limit women's access to such positions.

An argument linking under representation of women in management with sub-optimal levels of social justice is consistent with the perspective voiced by Nussbaum (2003), who has developed an extensive body of work extending Sen's contributions on capabilities to explicitly deal with the need to develop a specific set of capabilities relevant to gender. Without adequate access to positions of 
economic power within a given society, it is unlikely that women as a group are being afforded full opportunities to develop and use their capabilities. The lack of women in leadership positions also has implications for the unequal distribution of assets in the economy, which has serious implications for gender equity in many different spheres within society beyond the economy (Carmen Diana Deere and Cheryl R. Doss, 2006).

Theoretical and empirical research both suggest that the presence of women in management has implications for women as a whole, not simply for the women who occupy such positions. Because increases in the percentage of women in management positions may result in overall changes in the power dynamics within the economy, it is not at all surprising that personality research has focused on why personality traits exhibited by women will inhibit their movement into positions of greater relative power within the society, without any reference to the structure of power underlying these processes. To the extent that women achieve greater status within the labour market, power dynamics between men and women both within and outside of the labour market can change, shifting the balance of power towards greater overall equality between women and men in the different interacting spheres in which individuals operate, including the household, the market, the community and political arena.

Bina Agarwal (1997) developed a conceptual model in which she explores how women’s bargaining power is affected by direct and indirect interactions in the household, the market, the community, and the State. In her model, an increase in the overall status of women in the market would lead to greater bargaining power in all domains - even if one individual woman is not directly affected by the positive change, all women could theoretically enjoy enhanced bargaining power.

Status characteristics theory deals with the question of how inequalities in society as whole result in status differentials among groups within the society. It also deals with the maintenance of existing status differentials. Thus this theory presents one potential explanation concerning why the presence of women in leadership positions could have positive implications for women as a group both within the labour market and within the society as a whole. It also suggests why real or perceived personality differences will be used to impede women’s progress in achieving higher status jobs within 
the labour market. According to Joseph Berger and M. Hamit Fisek (2006), a status characteristic comprises four major features:

(1) a socially significant characteristic such as gender, race, and occupational position;

(2) states of the characteristic such as male-female, white-black, and higher-lower occupational positions, which can partition the relevant population;

(3) different status evaluations of these states relative to each other in terms of honour, prestige, and general social worth; and

(4) high and low conceptions of the generalized capacities of the individuals who possess these different states, where these high and low conceptions are consistent with the status evaluation of the states (p. 1039).

In an extension of their previous work (Joseph Berger et al., 1998; Joseph Berger, Cecilia L. Ridgeway and Morris Zelditch, 2002), they provide a mathematical proof of a number of theorems that purport to explain why a diffuse status characteristic, such as gender, may exist for a population at a given time if the members of that population hold differential status evaluations for males and females. The absence of females in leadership positions reinforces and maintains the perception that males are superior and more capable than women on a wide range of dimensions. Conversely, greater representation of women in leadership and high level managerial positions would over time lead to a different status characterization for women relative to men.

The theory of statistical discrimination holds that employers assess potential employees and promotion opportunities for current employees based on group characteristics as well as individual characteristics (Edmund Phelps, 1972). The rationale for such behaviour rests on the notion that information from any single, given individual is imperfect and that group membership provides additional information that needs to be considered in hiring and promotion decisions. The theory has usually been used to justify the existence of economic disadvantages for women, holding that all women are penalized because employers expect more intermittent labour market behaviour from women compared to men because of labour market withdrawals on account of childbirth and child rearing. 
To the extent that gender continues to be a category with practical implications within the labour market and within the society as whole, this theory predicts that increases in the number of women in management and leadership will have spill over effects for all women. This theory would predict that the positive group characteristics deriving from the labour market success of these women will be used to weight the characteristics of all women, including women who are not in these positions. With a more positive individual and group composite rating, the theory would predict that women as a whole would be offered better economic opportunities both at the point of labour market entry and beyond.

Empirical research does lend support to these theories. In an experimental study, Jeffrey Lucas (2003) found that the institutionalization of female leadership positively affected the influence of women in positions of authority. Based on data from the World Values Survey from 1990 to 2001, which covered over eighty countries, Stephanie Seguino (2007) found that gender norms shifted over the period under study and that women's economic empowerment was clearly one factor in the observed shift. A report by McKinsey \& Company (2007) found that companies with a greater percentage of women in management and leadership positions experienced positive impacts on both organizational excellence and on financial performance. In a Catalyst study examining the impact of women on corporate boards in Fortune 500 companies, Joy (2008) found that, on average, Fortune 500 companies with higher percentages of women board directors financially outperformed companies with the lowest percentage of women board members. The report concluded that "increasing the number of women on corporate boards is important for both financial performance and gender diversity in the corporate officer ranks (2008: 9).” Phillip N. Cohen and Matt L. Hoffman (2007) found that in the United States the presence of high - status managers had a large impact on reducing the extent of gender wage inequality.

\section{Theoretical Justification for the Big Five Personality Traits}

The Big Five personality traits (also referred to as the "Five Factor Model”) (Paul T. Costa \& Robert R. McCrae, 1992) are elements of an approach that organizes personality into five different dimensions. These five traits theoretically are intended to capture the concept of personality as extensively and exhaustively as possible. This approach classifies and organizes personality 
differences between individuals on the basis of five central dimensions, i.e. neuroticism (lack of emotional stability), extraversion, openness to experience, agreeableness and conscientiousness. As noted above, an extensive body of literature has shown that the Big Five are reasonable predictors of job performance and professional success, particularly for leaders and for the unemployed, however, inconsistencies have been observed across gender and across studies in terms of the specific observed effects.

\section{Theoretical Importance of Willingness to Take Risks}

As noted above, willingness to take risks has been shown to be a factor where differences are observed between men and women in survey research and a factor that is associated with labour market outcomes.

\section{Education and Demographic Variables}

Additional control variables included years of education, citizenship status, whether the individual was from East or West Germany, age, marital status and number of children under age 17. In the second estimation of change in the locus of control from 1999 to 2005, number of years in market work was also included as an explanatory variable ${ }^{\text {vii }}$.

\section{DATABASE AND VARIABLE DEFINITIONS}

The results of this study are based on the data of the Socio-Economic Panel (SOEP), 2007 release (1984-2006) (Gert Wagner, Joachim Frick, \& Jürgen Schupp, 2007). The SOEP is a representative longitudinal survey of more than 20,000 persons in about 12,000 private households in Germany. It has been carried out every year since 1984 with the same persons and families in the Federal Republic of Germany. The sample has been amended several times. Partial sample G from 2002, for example, provided significant numbers of cases for high-income households. ${ }^{\text {vii }}$

The initial survey covered 1,224 households with 2,671 persons. The SOEP was supplemented in 2006 by subsample $\mathrm{H}$, which is meant to stabilise the number of cases and serve as a form of “regeneration” (1,506 households with 2,616 persons). In total in 2006, there was information available for more than 22,000 respondents. On the basis of the SOEP data, analyses have been presented several times on the structure and remuneration of persons in specialist and leadership positions. ${ }^{\text {ix }}$ As the only long-term, longitudinal representative set of individual and household data in 
Germany, the SOEP provides a platform for examining not only socio-demographic and economic features but also information concerning personality traits and social indicators for a sufficiently high number of cases.

\section{Sample Selection}

The subjects in the study are employees between 28 and 60 years of age in the year 2001 in the private sector. The lower limit of age was chosen because of the relatively low number of individuals who have achieved high level managerial or leadership positions prior to age 28; the higher limit because of the factor of retirement. The range of years 2001 - 2005 was chosen because of the timing of when questions on locus of control and the Big Five personality traits were asked. Locus of control was included in the survey in 1999 and 2005; the Big Five personality traits were included for the first time in 2005.

\section{Variable Definitions}

Locus of control. In the SOEP, locus of control is surveyed with 10-items, which are based on work by Julian Rotter (1966). In 2005, all respondents were asked “To what degree do you personally agree with the following statements?” based on a seven point scale ranging from 1 =disagree completely to $7=$ agree completely. Based on a factor analyses, responses from the following nine statements were used to construct the measure of locus of control:

1. How my life goes depends on me

2. Compared to other people, I have not achieved what I deserve

3. What a person achieves in life is above all a question of fate or luck

4. I frequently have the experience that other people have a controlling influence over my life

5. One has to work hard in order to succeed

6. If I run up against difficulties in life, I often doubt my own abilities

7. The opportunities that I have in life are determined by the social conditions

8. Inborn abilities are more important than any efforts one can make

9. I have little control over the things that happen in my life. 
The same set of questions was first asked in 1999, however, the scale ranged from 1 to 4 . Hence we used standardized scores in the both of the two models. Higher values of locus of control in our models indicate higher levels of internal control.

Years in a leadership position. The endogenous variable, years in management / leadership position was calculated by adding the number of times from 2001 to 2005 that a respondent indicated that they were in a managerial or leadership position. The large number of definitions of leaders makes it difficult to compare the results of various studies, particularly over the course of time because "there are almost as many different definitions of leadership as there are persons who have attempted to define the concept (Bernard M. Bass, 1990: 11)”. In this study, leaders and high level managers are defined on the basis of the respondents' own comments on their position in their occupation. The target variable was the information on whether or not the respondent was in a leadership position in the years from 2001 - 2005. Due to the extremely low proportion of women in high leadership positions, a somewhat broader definition of leaders was selected. It encompasses persons (starting at age 28 in 2001) who stated in the SOEP that they worked as employees ${ }^{\mathrm{x}}$ in the private sector ${ }^{\mathrm{xi}}$ in:

1. functions with extensive managerial duties (e.g. managing director, manager, head of a large firm or concern);

2. other managerial functions or highly qualified duties (e.g. scientist, attorney, head of department).

The term “leaders” therefore encompasses both persons in leadership positions as well as highlyqualified specialists.

Years in unemployment. The endogenous variable, years with unemployment, was calculated by adding the number of years between 2001 and 2005 where the respondents indicated they had experienced a spell of unemployment.

Years in labour market. In the change in locus of control model, we also included years in labour market, which was calculated by adding the number of years where the individual was in the labour market, but did not occupy a high level position and did not experience unemployment.

The Big Five Personality traits. In 2005, in the style of the Big Five approach, the short version of the Big Five Inventory (BFI-S) was used for the first time in the main SOEP survey. The 
development of this brief scale (three questions were asked on a scale of 1 to 7 for each personality dimension) was preceded by a pre-test in the year 2004. Regarding validity and reliability, the results revealed satisfactory results (Jean-Yves Gerlitz and Jürgen Schupp, 2005). The surveying of personality dimensions in the SOEP in 2005 was based on the self-assessment of respondents on the basis of 15 adjectives used in colloquial language ${ }^{\text {xii }} \mathrm{A}$ factor analysis confirmed that it was possible to extract from these 15 statements the five personality dimensions identified in the Big Five Inventory literature discussed above ${ }^{x i i i}$ :

1.conscientiousness: does a thorough job; tends to be lazy; does things effectively and efficiently;

2. extraversion: is communicative, talkative; is outgoing, sociable; is reserved;

3. agreeableness: is sometimes somewhat rude to others; has a forgiving nature; is considerate and kind to others;

4. openness to experience: is original, comes up with new ideas; values artistic experiences; has an active imagination; and

5. neuroticism: worries a lot; gets nervous easily; is relaxed, handles stress well.

Willingness to take risks in one's profession. Willingness to take risks was added to the SOEP in 2004 and is also based on respondent's self-assessment of a number of different dimensions of risk taking. This study focused on willing to take risks in the professional sphere. The question in the SOEP is "People can behave differently in different situations. How would you rate your willingness to take risks in the following areas? in your occupation?” The scale ranged from 0 : risk averse to 10 : fully prepared to take risks.

Demographic variables. Finally, in our three stage estimation, we included demographic variables in year 2001: age, marital status ( $0=$ married, $1=$ single), number of children under 16 , whether the individual was from East Germany $(0=$ no, $1=$ yes) or was a foreigner ( $0=$ no, $1=y e s)$. In the model where we estimated change in locus of control, we included variables that measured whether the individual had a change in marital status (change to divorce and change to married $-0=$ no change, 1 = change occurred ; two variables that indicated changes in whether children were present 
(with children in household in 2005, but not in 2001 and with children in 2001, but none in household in 2005- $-0=$ no change, $1=$ change occurred) and also whether a change in citizenship status occurred.

\section{RESULTS}

Table 1 presents the descriptive statistics; Table 2 presents the results for the three stage least squares model; Table 3 presents the results for the change in locus of control model. In this section, we report our findings; in the following section, we discuss the meaning of these findings in terms of their gender implications.

\section{Years in high level managerial/leadership positions as predictor variable for locus of}

control. For both men and women, an increase in the number of years in high level managerial/leadership positions was associated in an increase in the level of locus of control in 2005. The same pattern was observed in the change in locus of control equation where the number of years in management/ leadership was associated with positive changes in the locus of control.

\section{Years in unemployment and in market work as predictor variables for locus of control.} Number of years in unemployment was associated with lower levels of locus of control in 2005 ( $\rho<$ .001) for both men and women, however, the relative size of the effect as measured by the estimated coefficient was over 1.5 times higher for men than for women (respectively -.097 for men and -.067 for women). In addition, the relative size of the estimated coefficients for unemployment exceeded the size of the estimated coefficients for years in managerial/leadership positions by a factor of approximately 2.5 for men and 1.5 for women. The same pattern was observed for change in locus of control. In the change in locus of control model, number of years in the market was not associated with a change in the locus of control.

Locus of control in 1999 as a predictor variable. Locus of control in 1999 was positively associated with locus of control in 2005 for both men and women. Results were also similar for women and men in terms of the power of locus of control to predict years of unemployment. For both genders, higher levels of locus of control were associated with fewer years in unemployment.

Differences were observed, however, in the association between initial level of locus of control and the predicted number of years in management/leadership. For men, locus of control was a significant $(\rho<$ 
.001) predictor of years in management/leadership, whereas for women, no association between locus of control in 1999 and years in management/leadership was observed.

The results in the change of locus of control equation also strongly confirmed previous research that locus of control is not a static personality trait. The results in Table 3 indicate that a regression to the mean process occurred between 1999 and 2005, that is, those with higher than average levels of locus of control in 1999 tended to report decreases in level of control over the observed time period, whereas those with lower than average levels tended to report increases in their locus of control.

Because z-scores for locus of control were used, the negative coefficient observed for locus of control in 1999 indicates that those with particularly large positive and negative deviations from the mean in 1999 had relatively large changes from 1999 to 2005 in the direction of the mean compared with those whose observed locus of control were closer to the sample mean.

To our knowledge, our finding that changes in locus of control showed a tendency of regression towards the mean is a finding that has not previously been reported in the literature. This particular finding suggests a direction for future research for locus of control. A potential hypothesis that could be investigated is that locus of control is similar to subjective well-being-a set point level of locus of control could exist that is subject to fluctuations from positive or negative life events. Most of these events might be associated with temporary fluctuations in the observed level of locus of control, with only more dramatic life experiences resulting in a shifting downward or upward of a baseline level that developed earlier in the course of personality development. If these events tend to accumulate, such as the length of time in positive labour market states, for example years in managerial/leadership positions or in negative labour market states, such as unemployment, long term changes in locus of control might occur. Given the strong associations noted above between locus of control and a wide range of non-labour market outcomes, more research is needed on what contributes to changing levels of locus of control across the life cycle.

Big Five Personality traits. Each of the Big Five Personality traits was strongly associated with the predicted level of locus of control in 2005. They were also significant predictors of the change in locus of control from 1999 to 2005. Positive associations were observed for men and women for conscientiousness, extraversion, and agreeableness; negative associations were observed for both 
genders for neuroticism. Men who reported a higher degree of openness to experience reported a lower level of locus of control in 2005 and a negative change in locus of control from 1999 to 2005. This association was not observed for women.

Similarities and differences were observed between men and women in the associations between the Big Five Personality Traits and years in unemployment and years in managerial/leadership positions. For neither men nor women were openness to experience and extraversion associated with number of years in the two employment states. For both men and women, neuroticism was associated with more years in unemployment, with the estimated coefficient for men 2.6 times as large as the estimated coefficient for women. Low scores on conscientiousness were associated with more years in unemployment for men, but not for women. High scores on this trait were associated with more years in management for women with no observed effect for men. Women who reported higher levels of agreeableness also reported fewer years in managerial/leadership positions, with no statistically significant relationship observed for years in unemployment. For men, this trait was not associated with number of years in either management or unemployment.

Willingness to take risks in one's own profession. No differences were observed between men and women in terms of the observed associations between willingness to take risks in one's career and the predicted number of years in high level positions. In the change in locus of control model, willing to take risks was associated with larger positive changes in the locus of control for men than for women.

Human capital and demographic variables. Increases in years of education were associated with increases in years in high level positions for men and women whereas men and women with fewer years of education reported more years with unemployment. For both endogenous variables, the size of the estimated coefficients for men exceeded those observed for women by a factor of approximately 2 for years in management and 1.5 for years with unemployment. Higher years of education were also associated with greater positive changes in locus of control from 1999 to 2005. Years in market work not marked by unemployment or work in high level employment was not associated with changes in the locus of control. 
As age increased, women tended to report lower levels of locus of control with no observed association for men. Although our data may reflect differences in locus of control for younger cohorts compared with older cohorts, past research has shown that locus of control for women does tend to decrease with age (Catherine E Ross and John Mirowsky, 2002). Increases in age were also associated with increases in the years in unemployment for men and women, with the estimated coefficient larger for men than for women. In the change in locus of control equation, increases in age were not associated with observed changes in locus of control between 1999 and 2005.

Foreigners (non-citizens) reported lower levels of locus of control, with the estimated coefficient for women exceeding that for men by a factor of 1.6. Foreign men had more reported years of unemployment whereas foreign women reported more years in management/leadership positions. East German men experienced more years of unemployment and fewer years in managerial positions than men in West Germany. For women, differences between those in the East and West were observed for years with unemployment, but not for years in managerial/leadership positions.

Men and women who were single both reported more years with unemployment than their married counterparts whereas single women reported more years in management/leadership positions than married women. No differences were observed between married and single men in the predicted number of years in management/leadership.

Number of children in the household under age 17 was associated with more years in unemployment for both men and women, with the estimated coefficient for women (.082) larger than the estimated coefficient for men (.051). Not surprisingly, this variable was the only variable where the estimated coefficient in the years in management/leadership was statistically significant for both men and women, but where the direction of the observed effects differed for the two genders. Men with more children in their household has more years in managerial/leadership positions than men with fewer or no children, but women with more children had fewer years in such positions compared with women with fewer or no children.

In the change in locus of control equation, only one of the variables measuring a change between 1999 and 2005 achieved conventional levels of statistical signification. Foreign women living in Germany who were not citizens in 1999 but who became German citizens sometime between 1999 and 
2005 reported a negative change in locus of control. A marginally significant effect was also observed for women who experienced a change in marital status. Women who became single during this period had negative changes in locus of control.

\section{DISCUSSION}

Our results fit within an already broad and continuously expanding literature examining links between locus of control, personality traits, labour market outcomes, and demographic and human capital variables. Hence the primary contribution of our work to the literature centres on its critique of existing theories; on its examination of three separate processes within the same model; and on its simultaneous focus on the most favourable and least favourable labour market outcomes as opposed to an exclusive focus on differences in earnings or on one of these outcomes, but not both. We begin our discussion by noting that the primary differences between genders occurred in the processes by which highly positive and negative labour market outcomes were determined versus the processes underlying the development of one particular aspect of personality, locus of control. That is the differences observed by gender were far more pronounced in the equation for years in managerial/ leadership positions than in the equation for locus of control. Negative labour states were also marked by differences by gender, but not to the same degree observed for positive states. Overall, our findings suggest that a greater degree of gender neutrality exists in terms of how personality, education and demographic variables influence the locus of control and the allocation of individuals to negative labour market states, that is unemployment, than exists in the allocation of individuals to highly positive labour market states.

In both the three equation model and in the change of locus of control model, four of the Big Five traits were related to level of locus of control and to observed changes in locus of control for both men and women. For these four traits, the direction of the observed relationship was the same for women and for men. The only trait for which gender differences was observed was Openness to Experience, which was associated with higher levels of locus of control in 2005 and positive changes between 1999 and 2005 for men but not for women. Willingness to take risks in occupation, another characteristic of personality, also operated similarly for men and women and increased the extent of self-reported positive change in locus of control. Furthermore positive and negative labour market 
outcomes also seemed to operate similarly for both genders in the association with locus of controlboth men and women reported higher levels and more positive change in locus of control, the more years they spent in high level positions, with an opposite association observed for years in unemployment. Hence, our findings provide stronger support to the hypothesis that these internal processes are similar for men and for women than to an alternative hypotheses that intrinsic and internal gender differences exist in how this specific aspect of personality develops and changes over time. Overall, these results provide strong support for the economic argument that labour market is not the neutral institution that it is presumed to be within traditional neoclassical theory.

Our results also lend support to our assertion in the introduction that personality traits are more useful in highlighting how gender functions as a social construct within the labour market than as additional explanatory variables that serve to reduce the unexplained gender differences in labour market outcomes. It is in the area of years in managerial/leadership positions that a more sharply delineated gendered process seems to be present in determining who is and who is not allowed ongoing access to high level positions within the labour market. Men with higher levels of locus of control reported more years in managerial / leadership positions, but no association was observed for women. On the other hand, women with higher levels of conscientiousness and lower levels of agreeableness reported more years in management/leadership positions than other women—a result not observed for men. Our findings are also consistent with long-standing observations that children hinder women's opportunities, while for men they have a bi-polar effect—men with greater numbers of children are both more likely to occupy high level positions within the labour market and more likely to be unemployed-a reflection of the demographics concerning the u-shape between income and number of children, that is, the rich and the poor tend to have more children than middle income families. For women, number of children was not associated with positive labour market outcomes.

The work presented here indicates that personality traits are qualitatively different from human capital variables in that these variables do not necessarily operate in a similar fashion for women and for men in terms of their relative influence on labour market outcomes. Our results confirm past research and indicate that the rewards and penalties associated with personality traits cannot be assumed to be the same for women and men. In contrast, the relationships between Big Five 
Personality traits and levels of locus of control are similar for men and for women. In terms of how periods of time spent in highly positive and in negative labour market states affect levels of locus of control, our results indicate that women and men respond in similar ways—-the size of their response differs, but the direction and significance are the same for both genders. As economists begin to explore the role of these variables more frequently in theoretical and empirical work, these distinctions are crucial. For processes where individuals have relatively greater control, such as how they respond to positive and negative labour market events in adjusting their perceived locus of control, our results indicate that men and women are similar in their responses. They are also similar in terms of the observed associations between their personalities as described by the Big Five Traits and their perceived locus of control. Individuals have, however, relatively less control in determining how the labour market as an institution rewards or penalizes them for their personality. And in this case, gender differences are more pronounced.

In human capital theory and empirical research, human capital variables operate similarly for women and men even though the observed rates of return may differ by gender. The same is true for the implications of the principal agent theories—-they are gender neutral with regards to how traits operate to affect labour market outcomes. These theories and the associated empirical work are not concerned with explaining qualitatively different processes for women compared with men. Human capital theory and empirical work focus on why gender differences occur in the level of the important predictor variables, such as years of full time experience accumulated in the market. In these models, discrimination may lead to lower rates of return for women; institutional arrangements and social norms regarding the division of caring labour may impede the ability of women as a group to participate in the labour market on an equal footing with men as a group, but the basic processes confronting men and women in the labour market are held to be the same. Within human capital theory and principal agent theory, institutional arrangements and social norms that disadvantage women are not considered to impede efficient market functioning.

For economists working from a non-traditional perspective, the inclusion of personality traits offers yet another possibility to challenge economic dogma and to highlight the limitations of human capital and other mainstream economic theories in accounting for gender differences in labour market 
outcomes. As discussed above, the Big Five Personality Traits are considered by psychologists to be descriptions of personality that do not have separate meanings for women versus men, therefore, it is difficult to find easy explanations within conventional economic theory for why the labour market rewards and penalizes men and women differently when they possess similar personality traits. Akerlof and Kranton do allow for differences to exist, if identity is associated with different personality traits, but the lack of attention in their model to asymmetries in outcomes when women compared with men balance the effects of different elements of their utility functions only serves to make the gains to men and to firms invisible when identity is used to maintain a status quo that penalizes women as a group.

The work of Julie Nelson $(1992,1999)$ and other alternative economists may be a useful starting point in refining and extending labour market theory to incorporate these inconvenient observations. Building on the work of Nelson, we can argue that Western market economies are marked by an apparent psychological need to form dualistic, hierarchical categories, with the consequences of this need clearly reflected within the discipline of economics. To the extent that dualistic gender metaphors exist within the market, personality is filtered first through the lens of gender where men are above and women below, which then results in the contradiction that men and women may be treated differently even though two individuals of different genders may in fact be similar in terms of personality traits. When men and women with the same attributes are assessed by the institution of the market, women's attributes may routinely be assessed in terms of the myths surrounding women and the care giving role. Even within high status positions within the market, women are first classified as women with the entire set of associated negative connotations found within a dualistic, hierarchical, metaphorical worldview. With such an understanding, mechanisms for change centre on changing the institutions and theories that incorporate the implicit understanding that a gender hierarchy exists and not on urging individual women and men to transform their personalities so that they may obtain better labour market outcomes.

Changes in personality traits may occur, however, as a result of changes in labour market institutions—not as a prerequisite, but as a consequence. How this process could occur can be seen through the lens of "neuroticism” and "attitudes towards risk". The labelling of the personality trait, 
neuroticism, connotes a negative personality characteristic, without reference to what is likely the invisible link between neuroticism and caring. As pointed out by M.V. Lee Badgett and Nancy Folbre (1999), the American Heritage Dictionary gives two negative definitions of the noun care: (1) a burdened state of mind, as that arising from heavy responsibilities; worry and (2) Mental suffering grief. As a verb, the dictionary defines care as (1) to be concerned or interested and (2) to provide needed assistance or watchful supervision. Badgett and Folbre argue that "the upshot may be that to be concerned or interested is to assume a burden (p. 312). “ To score high on the "neuroticism” dimension of the Big Five is to indicate that one worries a lot; gets nervous easily; and is not relaxednatural human reactions among those who have assumed a burden and who have heavy responsibilities. The almost universal penalty (or at least lack of reward) for this characteristic, together with the negative implications of its label, may thus be a screen for using personality to bar women from high level occupations and to ensure that they continue to assume the majority of the caring responsibilities needed by any society to survive. If caring did not entail carrying a heavy burden, personality changes might be observed among caregivers. Were men to assume greater care responsibilities, perhaps they would find themselves worrying more and carrying a higher burden. But the literature on negative returns to neuroticism generally shows that men incur even greater penalties than women if they exhibit this trait; the labour market apparently finds it useful to provide disincentives for men to carry the burden of care.

If men were less likely to occupy high status positions within the labour market, their recklessness (a less positive labelling of individuals with high tolerances toward risk) might decrease and the society might be better off as a whole. In conclusion, an explicitly value-laden analysis of the rewards associated with personality within the labour market could expose areas where inefficiencies exist in terms of social and economic justice; it could expose areas where the gendered nature of rewards by personality serves to perpetuate power relationships within the labour market that ultimately serve to undermine the ability of the economy to function most effectively for all of its members, not just selected groups. 


\section{Bibliography}

AFL-CIO. 2011. “Executive Pay Watch”, retrieved on May 18, 2011 at http://www.aflcio.org/corporatewatch/paywatch/ceopay.cfm.

Akerlof, George A. and Rachel E. Kranton. 2000. “Economics and Identity.” The Quarterly Journal of Economics, 115(3): 715-753.

Andersen, Signe Hald. 2009. “Unemployment and Subjective Well-Being: A Question of Class?” Work and Occupations, 36(1): 3-25.

Andresen, Burghard. 1995. "Risikobereitschaft (R) - der sechste Basisfaktor der Persönlichkeit: Konvergenz multivariater Studien und Konstruktexplikation. ” Zeitschrift für Differentielle und Diagnostische Psychologie, 16(4): 210-236.

Agarwal, Bina. 1997. "'Bargaining' and Gender Relations: Within and Beyond the Household." Feminist Economics, 3(1): 1-51.

Artazcoz, Lucia, Joan Benach, Carme Borrell, and Immaculada Cortes. 2004. "Unemployment and Mental Health: Understanding the Interactions among Gender, Family Roles, and Social Class.” American Journal of Public Health, 94(1): 82-88.

Babcock, Linda and Sara Laschever. 2003. Women Don't Ask: Negotiation and the Gender Divide. Princeton, NY: Princeton University Press.

Badgett, M.V. Lee and Nancy Folbre. 1999. "Assigning Care: Gender Norms and Economic Outcomes.” International Labour Review. 138(3): 311-326.

Barnet, Helen S. 1990. "Divorce Stress and Adjustment Model: Locus of Control and Demographic Predictors.” Journal of Divorce, 13(3): 93-109.

Barrick, Murray R. and Michael K. Mount. 2001. “The Big Five Personality Dimensions and Job Performance: A Meta-Analysis.” Personnel Psychology, 44: 1-26.

Barrick, Murray R. and Michael K. Mount. 2005. "Yes, Personality Matters: Moving On to More Important Matters.” Human Performance, 18(4): 359-372.

Barrick, Murray R., Michael K. Mount, and Timothy A. Judge. 2001. "Personality and Performance at the Beginning of the New Millennium: What Do We Know and Where Do We Go Next?” [Special Issue], International Journal of Selection and Assessment, 9: 9-30.

Bass, Bernard M. 1990. Bass \& Stogdill's Handbook of Leadership: Theory, Research and Managerial Applications. New York: Free Press.

Becker, Gary S. 1971. The Economics of Discrimination. Chicago: The University of Chicago Press.

Bebchuk, Lucian A. and Holger Spamann. 2010. "Regulating Bankers’ Pay.” Georgetown Law Journal, 98(2): 247-287.

Belsley, David A. 1988. "Two or Three Stages of Least Squares?" Computational Science in Economics and Management. 1: 21-30.

Berger, Joseph and M. Hamit Fisek. 2006. "Diffuse Status Characteristics and the Spread of Status Value: A Formal Theory.” American Journal of Sociology, 111(4): 1038-79. 
Berger, Joseph, M Hamit Fisek, Cecilia L. Ridgeway, and Robert Z. Norman. 1998. "The Legitimation and Delegitimation of Power and Prestige Orders.” American Sociological Review, (63)3: 379-405.

Berger, Joseph, Cecilia L. Ridgeway and Morris Zelditch. 2002. "Construction of Status and Referential Structures." Sociological Theory, 20(2): 157-179.

Bertrand, Marianne. 2010. “New Perspectives on Gender.” pp. 1545 - 1591 in Orley Ashenfelter and David Card, Eds., Handbook of Labor Economics.

Borghans, Lex, Angela Lee Duckworth, James J. Heckman and Bas ter Weel. 2008. "The Economics and Psychology of Personality Traits.” The Journal of Human Resources, XLIII (4): 972-1059.

Borghans, Lex, Bas ter Weel, and Bruce A. Weinberg. 2005. People: Social Capital and the LaborMarket Outcomes of Underrepresented Groups. IZA Discussion Paper 1494.

Boudreau, John W., Wendy R. Boswell, and Timothy A. Judge. 2001. "Effects of Personality on Executive Career Success in the United States and Europe.” Journal of Vocational Behavior, 58(1): 53-81.

Bowles, Samuel and Herbert Gintis. 2002. “The Inheritance of Inequality.” Journal of Economic Perspectives, 16(3): 3-30.

Bowles, Samuel and Herbert Gintis. 2001. "Schooling in Capitalist America Revisited.” Sociology of Education, 75(2): 1 - 18.

Bowles, Samuel, Herbert Gintis, and Melissa Osborne. 2001. "Incentive-Enhancing Preferences, Behavior, and Earnings.” The American Economic Review 91(2): 155-158.

Bowles, Samuel and Herbert Gintis. 1976. Schooling in Capitalist America. Basic Books.

Braakmann, Nils. 2009. "The Role of Psychological Traits for the Gender Gap in Full-Time Employment and Wages: Evidence from Germany.” SOEP Papers on Multidisciplinary Panel Data Research, No. 162. DIW Berlin.

Brandstätter, Hermann. 1999. "Veränderbarkeit von Persönlichektismerkmalen - Beiträge der differentiellen Psychologie.” In K.-H. Sonntag (Hrsg.), Personalentwicklung in Organisationen. Psychologische Grundlagen, Methoden und Strategien (S. 51-76). Göttingen, Bern, Toronto, Seattle: Hogrefe Verlag.

Broman, Clifford, V. Lee Hamilton, William S. Hoffman, and Roya Mavaddat. 1995. "Race, Gender, and the Response to Stress: Autoworkers' Vulnerability to Long-Term Unemployment.” American Journal of Community Psychology, 23: 813-838.

Busch, Anne and Elke Holst. 2009. "Glass Ceiling Effect and Earnings - The Gender Pay Gap in Managerial Positions in Germany.” Discussion Papers 905, Deutsches Institut für Wirtschaftsforschung (DIW Berlin), Berlin.

Clark, Andrew E., Yannis Georgellis, and Petter Sanfey. 2001. "Scarring: The Psychological Impact of Past Unemployment.” Economica, 68, 221-241.

Clark, Andrew. E. and Andrew J. Oswald.1994. "Unhappiness and Unemployment.” The Economic Journal, 104: 648-659. 
Cole, Kenneth, Anne Daly, and Anita Mak. 2009. "Good for the Soul: The Relationship between Work, Wellbeing, and Psychological Capital.” The Journal of Socio-Economics, 38: 464-474.

Costa, Paul T. and Robert R. McCrae. 1992. Revised NEO Personality Inventory (NEO PIR) and NEO Five Factor Inventory. Professional Manual. Odessa, Florida: Psychological Assessment Resources.

Croson, Rachel and Uri Gneezy. 2009. “Gender Differences in Preferences.” Journal of Economic Literature, 47(2): 448-474.

Cunha, Flavio and James J. Heckman. 2007. “The Technology of Skill Formation.” American Economic Review Papers and Proceedings, 97(2): 31-47.

Cunha, Flavio \& James J. Heckman. 2008. "Formulating, Identifying and Estimating the Technology of Cognitive and Noncognitive Skill Formation.” The Journal of Human Resources, XLIII (4): 738782.

Darity, William, Jr. and Arthur Goldsmith. 1996. “Social Psychology, Unemployment, and Macroeconomics.” Journal of Economic Perspectives, 10(1): 121-140.

Deere, Carmen Deere and Cheryl R. Doss. 2006. "The Gender Asset Gap: What Do we Know and Why Does It Matter?” Feminist Economics, 12(1-2): 1-50.

Diener, Ed, Eunkook M. Suh, Richard E. Lucas and Heidi L. Smith. 1999. "Subjective Well-Being: Three Decades of Progress.” Psychological Bulletin, 125: 276-302.

Di Tella, Rafael, Robert J. MacCulloch, and Andrew J. Oswald. 2003. "The Macroeconomics of Happiness.” The Review of Economics and Statistics, 85(4): 809-827.

Cohen, Phillip N. and Matt L. Huffman. 2007. "Working for the Woman? Female Managers and the Gender Wage Gap.” 72: 681-704.

Commission of the European Communities. (2009) Commission staff working document Accompanying document to the Report from the Commission to the European Parliament, the Council, the European Economic and Social Committee and the Committee of the Regions - Equality between Women and Men - $2009\{\operatorname{COM}(2009) 77$ final $\}$, retrieved on December 17, 2009, http://eur-lex.europa.eu/LexUriServ/LexUriServ.do?uri=SEC:2009:0165:FIN:EN:DOC

European Commission. (2009). Gender Balance in Decision-Making. European Commission, Employment, Social Affairs, and Equal Opportunities. Retrieved on December 17, 2009, http://ec.europa.eu/social/main.jsp?catId=762\&langId=en

Ford-Gilboe, Marilyn. 1997. "Family Strengths, Motivation, and Resources as Predictors of Health Promotion Behaviour in Single-Parent and Two-Parent Families.” Research in Nursing and Health, 20: 205-217.

Frey, Bruno, and Alois Stutzer, A. 2002. “What Can Economists Learn from Happiness Research?” Journal of Economic Literature, XL, 402-435.

Furnham, Adrian, John Crump, and Josh Whelan. 1997. "Validating the NEO Personality Inventory using Assessor’s Ratings.” Personal Individual Differences, 22: 669-675.

Gerlitz, Jean-Yves and Jürgen Schupp. 2005. Zur Erhebung der Big-Five-basierten Persönlichkeitsmerkmale im SOEP. Research Notes 4, Deutsches Institut für Wirtschaftsforschung (DIW Berlin), Berlin. 
Goldsmith, Arthur H., Jonathan R. Veum, and William Darity, Jr. 1996. "The Psychological Impact of Unemployment and Joblessness.” Journal of Socio-Economics, 25(3): 333-358.

Gray, Samuel R. and Albert A. Cannella, Jr. 1997. "The role of risk in executive compensation. “ Journal of Management 23(4): 517-540.

Groves, Melissa Osborne. 2005. "How Important Is Your Personality? Labor Market Returns to Personality for Women in the US and UK.” Journal of Economic Psychology, 26: 827-841.

Growe, Jennifer, D. 2007. "Reform the EEOC Guidelines: Protect Employees from Gender Discrimination as Mandated by Title VII.” Journal of Law and Policy, 24: 275-300.

Hacker, J. S., \& Pierson, P. (2010). Winner-Take-All Politics: Public Policy, Political Organization, and the Precipitous Rise of Top Incomes in the United States. Politics and Society, 38(2), 152-204.

Hatemi, Peter K., Sarah E. Medland, Lindon, J. Eaves. 2009. "Do Genes Contribute to the 'Gender Gap'?” The Journal of Politics, 71(1): 262-276.

Heckman, James J., Jora Stixrud, and Sergio Urzua. 2006. "The Effects of Cognitive and Noncognitive Abilities on Labor Market Outcomes and Social Behaviour.” The Journal of Labor Economics, 24(3): 411-482.

Heady, Bruce. 2008. "Life Goals Matter to Happiness: A Revision of Set-Point Theory.” Social Indicators Research, 86: 213-231.

Hill, Lisa C. and Jeanne M. Hilton. 1999. "Changes in Roles following Divorce: Comparison of Factors Contributing to Depression in Custodial Single Mothers and Custodial Single Fathers.” Journal of Divorce and Remarriage, 31(3-4): 91-114.

Holst, Elke. 2006. Women in Managerial Positions in Europe: Focus on Germany. Discussion Paper 557, Deutsches Institut fürWirtschaftsforschung (DIW Berlin).

Holst, Elke. (2009). Führungskräfte-Monitor 2001-2006 Forschungsreihe Band 7, Baden-Baden: Nomos-Verlag.

Holst, Elke, Marianne Ferber and Wenzel Matiaske. (Eds.) 2006. "Women in Management, Academia, and Other Professions: Stagnation or Progress?” Bd. 17 in Special Issue Management Revue, Mering: Hampp Verlag.

Holst, Elke and Julia Schimeta. 2009. Nach wie vor kaum Frauen in den Top-Gremien großer Unternehmen. Wochenbericht des DIW Berlin, 76, 18, 302-311.

Joseph, Jay .2002.Twin Studies in Psychiatry and Psychology: Science or Pseudoscience?” Psychiatric Quarterly, 7(1): 71-82.

Jones, Sheila. 2008. “Not 'Part of the Job’: Sexual Harassment Policy in the U.S., The Equal Employment Opportunity Commission, and Women’s Economic Citizenship, 1975-1991. Dissertation, Graduate College of Bowling Green State University.

Jordon-Young, Rebecca M. 2010. Brain Storm: The Flaws in the Science of Sex Differences. Cambridge: Harvard University Press.

Joy, Lois. 2008. Advancing Women Leaders: The Connection between Women Board Directors and Women Corporate Officers. New York: Catalyst. 
Judge, Timothy A. and Joyce E. Bono. 2001. "Relationship of Core Self-Evaluations Traits—SelfEsteem, Generalized Self-Efficacy, Locus of Control, and Emotional Stability—with Job Satisfaction and Job Performance: A Meta-Analysis.” Journal of Applied Psychology 86(1): 80-92.

Judge, Timothy A. and Charlice Hurst. 2007. "Capitalizing on one’s advantages: Role of core selfevaluations.”' Journal of Applied Psychology 92(5):1212-27.

Littmann-Wernli, Sabina and Renate Schubert. 2001. "Frauen in Führungpositionen - Ist die "gläserne Decke" diskriminierend? '” Arbeit - Zeitschrift für Arbeitsforschung, Arbeitsgestaltung und Arbeitspolitik, 10(2): 135-148.

Lucas, Jeffrey W. 2003. “Status Processes and the Institutionalization of Women as Leaders.” American Sociological Review, 68: 464-480.

McKinsey \& Company. 2007. Women Matter: Gender Diversity, A Corporate Performance Driver. New York: McKinsey \& Company.

Menaghan, Elizabeth G. and Toby L. Parcel. 1991. "Determining Children’s Home Environment: The Impact of Maternal Characteristics and Current Occupational and Family Conditions.” Journal of Marriage and the Family, 53(2): 417-431.

Mertler, Craig A. and Rachel A. Vannatta. 2005. Advanced and Multivariate Statistical Methods, Third Edition. Glendale, CA: Pyrczak Publishing.

Mueller, Gerrit and Erik Plug. 2006. "Estimating the Effect of Personality on Male and Female Earnings.” Industrial \& Labor Relations Review, 60(1): 1-22.

Murray, Cynthia L., Lan Gien, Shirley M. Solberg. 2003. “A Comparison of the Mental Health of Employed and Unemployed Women in the Context of a Massive Layoff.” Women \& Health, 37(2): 55-72.

Nelson, Julie A. 1992. “Gender, Metaphor, and the Definition of Economics.” Economics and Philosophy, 8: 103-125.

Nelson, Julie A. 1999. “On Markets and Martyrs: Is It Okay to Pay Well for Care?” Feminist Economics, 53(3): 43-59.

Ng, Thomas, W.H., Kelly L. Sorensen, and Lillian T. Eby. 2006. "Locus of Control at Work: A MetaAnalysis.” Journal of Organizational Behavior, 27: 1057-1087.

Ng, Thomas W.H., Lillian T. Eby, Kelly L. Sorensen, and Daniel C. Feldman. 2005. "Predictors of Objective and Subjective Career Success: A Meta-Analysis.” Personnel Psychology, 58: 367-408.

Noor, Noraini M. 2002. "Work-Family Conflict, Locus of Control, and Women’s Well-Being: Tests of Alternative Pathways.” The Journal of Social Psychology, 142(5): 645-662.

Nussbaum, Martha C. 2003. "Capabilities as Fundamental Entitlements: Sen and Social Justice.” Feminist Economics, 9(2-3): 33-59.

Peterson, Christopher. 2003. Personal Control and Well-Being. In D. Kahneman, E. Diener, \& N. Schwarz (Eds.), Well-being: The Foundations of Hedonic Psychology (pp. 288-301). New York: Russell Sage Foundation.

Phelps, Edmund S. 1972. "The Statistical Theory of Racism and Sexism.” American Economic Review, 62(4): 659-661. 
Piedmont, Ralph and Harold Weinstein. 1994. "Predicting Supervisor Ratings of Job Performance Using the NEO personality inventory.” The Journal of Psychology, 128: 225-265.

Ross, Catherine E. and John Mirowsky. 2002. "Age and the Gender Gap in the Sense of Personal Control. “ Social Psychology Quarterly, 65(2): 125-145.

Rotter, Julian B. 1966. "Generalized Expectancies for Internal versus External Control of Reinforcements.” Psychological Monographs, 80, Whole No. 609.

Salgado, Jesus F. 1997. "The Five Factor Model of Personality and Job Performance in the European Community.” Journal of Applied Psychology, 828(81): 30-43.

Seguino, Stephanie. 2007. "Plus Ça Change? Evidence on Global Trends in Gender Norms and Stereotypes.” Feminist Economics, 13(2): 1-28.

Spreckelmeyer, Katja N., Soeren Krach, Gregor Kohls, Lena Rademacher, Arda Irmak, Kerstin Konrad, Tilo Kircher, and Gerhard Gruender. 2009. „Anticipation of Monetary and Social Reward Differently Activates Mesolimbic Brain Structures in Men and Women. “ Scan, 4: 158-165.

Srivastava, Sanjay, Oliver P. John, Samuel D. Gosling, and Jeff Potter. 2003. "Development of Personality in Early and Middle Adulthood: Set like Plaster or Persistent Change?” Journal of Personality and Social Psychology, 84(5): 1041-1053.

Stringer, Sharon A. and Annette M. la Greca, 1985. "Correlates of Child Abuse Potential.” Journal of Abnormal Child Psychology, 13(2): 217-226

Ström, Sara. 2003. "Unemployment and Families: A Review of Research.” Social Service Review, 77: 399-430.

Sundquist, Kristina, Holger Theobald, Min Yang, Min, Xinjun Li, Sven-Erik Johansson, and Jan Sundquist. 2006. "Neighbourhood Violent Crime and Unemployment Increase the Risk of Coronary Heart Disease: A Multilevel Study in an Urban Setting.” Social Science and Medicine 62: 2061-2071.

Tett, Robert P., Douglas N. Jackson, and Mitchell Rothstein. 1991. "Personality Measures as Predictors of Job Performance: A Meta-Analytic Review.” Personnel Psychology, 44:703-742.

Vilhjalmsson, R., Krisjansdottir, G., \& Sveinbjarnardottir, E. 1998. "Factors Associated with Suicide Ideation in Adults.” Social Psychiatry and Psychiatric Epidemiology. 33(3): 97-103.

Wagner, Gert G., Joachim Frick, and Jürgen Schupp. 2007. "The German Socio Economic Panel Study (SOEP) - Scope, Evolution and Enhancements.” Schmollers Jahrbuch -Zeitschrift für Wirtschafts- und Sozialwissenschaften, (127): 1, 139-169.

Welsch, Heinz and Udo Bonn. 2008. "Economic Convergence and Life Satisfaction in the European Union.” The Journal of Socio-Economics, 37: 1153-1167.

Winkelmann, Liliana and Rainer Winkelmann. 1998. "Why Are the Unemployed So Unhappy?” Economica, 65: 1-15.

Wolak, Jennifer and George E. Marcus. 207. "Personality and Emotional Response: Strategic and Tactical Responses to Changing Political Circumstances.” Annals, AAPSS, 614: 172- 195.

Yamada, David C. 2009. "Workplace Bullying and American Employment Law: A Ten-Year Progress Report and Assessment.” Legal Studies Research Paper, Research Paper 09-49, Suffolk University Law School. 
Zunzunegui, Maria-Victoria, Mathieu Foster, Lise Gauvin, Marie-France Raynault, J. Douglas Willms. 2006. “Community Unemployment and Immigrants' in Montreal.” Social Science and Medicine, 63: 485-500.

Zyphur, Michael. J., Jayanth Narayan, Richard D. Arvey, and Gordon J. Alexander. 2009. "The Genetics of Economic Risk Preferences.” Journal of Behavioral Decision Making, 22: 367-377. 
Table 1. Descriptive Statistics

\begin{tabular}{|c|c|c|c|c|}
\hline & \multicolumn{2}{|c|}{ Male } & \multicolumn{2}{|c|}{ Female } \\
\hline & $\begin{array}{c}\text { Mean or } \\
\text { percent }\end{array}$ & $\begin{array}{l}\text { Standard } \\
\text { Deviation }\end{array}$ & $\begin{array}{l}\text { Mean or } \\
\text { percent }\end{array}$ & $\begin{array}{l}\text { Standard } \\
\text { Deviation }\end{array}$ \\
\hline $\begin{array}{l}\text { Locus of control, } 2005 \\
\text { (non-standardized, z-scores used in analyses) }\end{array}$ & 39.05 & 7.13 & 38.11 & 6.94 \\
\hline $\begin{array}{l}\text { Locus of control, } 1999 \text { (non-standardized, z- } \\
\text { scores used in analyses) }\end{array}$ & 12.93 & 3.40 & 13.51 & 3.28 \\
\hline Years in managerial/leadership positions & 0.71 & 1.53 & 0.28 & 0.96 \\
\hline Years with unemployment & 0.39 & 0.98 & 0.36 & 0.94 \\
\hline Openness to experience & 13.18 & 3.45 & 13.68 & 3.64 \\
\hline Conscientiousness & 17.90 & 2.69 & 18.18 & 2.53 \\
\hline Extraversion & 14.12 & 3.29 & 14.77 & 3.36 \\
\hline Neuroticism & 11.32 & 3.52 & 12.59 & 3.61 \\
\hline Agreeableness & 15.78 & 2.97 & 16.80 & 2.77 \\
\hline Willingness to take risks in occupation & 4.09 & 2.59 & 3.22 & 2.50 \\
\hline Age in 2001 & 43.05 & 9.09 & 42.90 & 9.13 \\
\hline Years of education, 2001 & 12.26 & 2.67 & 11.93 & 2.50 \\
\hline Foreigner, 2001 & $10 \%$ & & $10 \%$ & \\
\hline East German & $24 \%$ & & $24 \%$ & \\
\hline Single & $28 \%$ & & $27 \%$ & \\
\hline Number of children in household, 2001 & .78 & 1.019 & .80 & 1.011 \\
\hline $\begin{array}{l}\text { Additional Variables in Change in Locus of } \\
\text { Control, 1999-2005 }\end{array}$ & & & & \\
\hline $\begin{array}{l}\text { Years in Market with no spell of unemployment } \\
\text { or managerial/leadership position }\end{array}$ & 3.36 & 2.04 & 3.10 & 2.03 \\
\hline Change to Single/Divorced from Married & $4.9 \%$ & & $3.9 \%$ & \\
\hline Change to Married from Single/Divorced & $3.7 \%$ & & $4.5 \%$ & \\
\hline Children in household in 2005, none in 2001 & $4.7 \%$ & & $3.2 \%$ & \\
\hline Children in household in 2001, none in 2005 & $11.7 \%$ & & $11.7 \%$ & \\
\hline Became German Citizen & $0.8 \%$ & & $0.6 \%$ & \\
\hline Number of cases & 2719 & & 2871 & \\
\hline
\end{tabular}




\begin{tabular}{|c|c|c|c|c|c|c|}
\hline \multirow[b]{2}{*}{ Variables. } & \multicolumn{3}{|c|}{ Males } & \multicolumn{3}{|c|}{ Females } \\
\hline & $\begin{array}{l}\text { Locus of control } \\
2005\end{array}$ & $\begin{array}{c}\text { Years with } \\
\text { unemployment }\end{array}$ & $\begin{array}{l}\text { Years in } \\
\text { managerial } \\
\text { /leadership } \\
\text { positions }\end{array}$ & $\begin{array}{l}\text { Locus of control } \\
2005\end{array}$ & $\begin{array}{c}\text { Years with } \\
\text { unemployment }\end{array}$ & $\begin{array}{l}\text { Years in } \\
\text { managerial/ } \\
\text { leadership } \\
\text { positions }\end{array}$ \\
\hline \multicolumn{7}{|l|}{$\begin{array}{l}\text { Endogenous } \\
\text { Variables }\end{array}$} \\
\hline \multirow[t]{2}{*}{$\begin{array}{l}\text { Years with } \\
\text { unemployment }\end{array}$} & $-.097 * * *$ & & & $-.062 * * *$ & & \\
\hline & $(.015)$ & & & $(.015)$ & & \\
\hline \multirow[t]{2}{*}{ Years in management } & $.037 * * *$ & & & $.049 * * *$ & & \\
\hline & $(.009)$ & & & $(.014)$ & & \\
\hline Locus of control 1999 & $.395 * * *$ & $-.053^{* *}$ & $.089 * * *$ & $.380 * * *$ & $-.063 * *$ & .020 \\
\hline (z-score) & $(.016)$ & $(.019)$ & $(.028)$ & $(.016)$ & $(019)$ & $(.020)$ \\
\hline \multicolumn{7}{|l|}{ Personality Traits } \\
\hline \multirow[t]{2}{*}{$\begin{array}{l}\text { Openness to } \\
\text { Experience }\end{array}$} & $-.014 * *$ & .000 & .004 & -.002 & .005 & -.002 \\
\hline & $(.005)$ & $(.006)$ & $(.008)$ & $(.004)$ & $(.005)$ & $(.005)$ \\
\hline \multirow[t]{2}{*}{ Conscientiousness } & $.068 * * *$ & $-.035 * * *$ & .014 & $.047 * * *$ & -.002 & $.022 * *$ \\
\hline & $(.006)$ & $(.007)$ & $(.010)$ & $(.006)$ & $(.007)$ & $(.007)$ \\
\hline \multirow[t]{2}{*}{ Extraversion } & $.039 * * *$ & .006 & -.007 & $.028 * * *$ & -.002 & -.001 \\
\hline & $(.005)$ & $(.006)$ & $(.009)$ & $(.005)$ & $(.005)$ & $(.006)$ \\
\hline \multirow[t]{2}{*}{ Neuroticism } & $-.057 * * *$ & $.034 * * *$ & & $-.056 * * *$ & $.013^{* *}$ & \\
\hline & $(.005)$ & $(.006)$ & & $(.004)$ & $(.005)$ & \\
\hline \multirow[t]{2}{*}{ Agreeableness } & $.025 * * *$ & .006 & -.011 & $.035 * * *$ & .001 & $-.027 * * *$ \\
\hline & $(.005)$ & $(.007)$ & $(.010)$ & $(.006)$ & $(.007)$ & $(.007)$ \\
\hline \multirow[t]{2}{*}{ Risk taking in career } & & & $.026^{*}$ & & & $.027 * * *$ \\
\hline & & & $(.011)$ & & & $(.008)$ \\
\hline \multirow[t]{2}{*}{ Years of Education } & & $-.073 * * *$ & $.340 * * *$ & & $-.047 * * *$ & $.172 * * *$ \\
\hline & & $(.007)$ & $(.010)$ & & $(.007)$ & $(.007)$ \\
\hline \multicolumn{7}{|l|}{ Demographic Variables } \\
\hline \multirow[t]{2}{*}{ Foreigner } & $-.170 * * *$ & $.213^{* * * *}$ & .060 & $-.272 * * *$ & .036 & $.169 * * *$ \\
\hline & $(.051)$ & $(.060)$ & $(.087)$ & $(.052)$ & $(.060)$ & $(.061)$ \\
\hline \multirow[t]{2}{*}{ East Germany } & -.031 & $.445 * * *$ & $-.335 * * *$ & -.043 & $.549 * * *$ & .057 \\
\hline & $(.035)$ & $(.042)$ & $(.062)$ & $(.034)$ & $(.041)$ & $(.042)$ \\
\hline
\end{tabular}




\begin{tabular}{|c|c|c|c|c|c|c|}
\hline \multicolumn{7}{|c|}{$\begin{array}{c}\text { Table 2. cont. } \\
\text { Maximum Likelihood Estimation of Three Equation Simultaneous Equation Model } \\
\text { Locus of Control, Years with Unemployment, Years in Management }\end{array}$} \\
\hline & \multicolumn{3}{|c|}{ Males } & \multicolumn{3}{|c|}{ Females } \\
\hline Variables. & $\begin{array}{l}\text { Locus of control } \\
2005\end{array}$ & $\begin{array}{c}\text { Years with } \\
\text { unemployment }\end{array}$ & $\begin{array}{l}\text { Years in } \\
\text { managerial } \\
\text { /leadership } \\
\text { positions }\end{array}$ & $\begin{array}{c}\text { Locus of control } \\
2005\end{array}$ & $\begin{array}{c}\text { Years with } \\
\text { unemployment }\end{array}$ & $\begin{array}{l}\text { Years in } \\
\text { managerial/ } \\
\text { leadership } \\
\text { positions }\end{array}$ \\
\hline \multirow[t]{2}{*}{ Age } & -.001 & $.013 * * *$ & .002 & $-.005 * * *$ & $.006 * * *$ & -.001 \\
\hline & $(.002)$ & $(.002)$ & $(.003)$ & $(.002)$ & $(.002)$ & $(.002)$ \\
\hline \multirow[t]{2}{*}{ Single } & -.070 & $.208 * * *$ & -.054 & -.008 & $.235^{* * *}$ & $.104 *$ \\
\hline & $(.036)$ & $(.043)$ & $(.062)$ & $(.036)$ & $(.042)$ & $(.043)$ \\
\hline \multirow[t]{2}{*}{$\begin{array}{l}\text { Number of children } \\
\text { under age } 17\end{array}$} & .000 & $.051^{* *}$ & $.071^{* *}$ & .012 & $.082 * * *$ & $-.087 * * *$ \\
\hline & $(.016)$ & $(.019)$ & $(.0211)$ & $(.017)$ & $(.019)$ & $(.019)$ \\
\hline Obs & \multicolumn{3}{|c|}{2697} & \multicolumn{3}{|c|}{2793} \\
\hline R-squared & .30 & .12 & .30 & .25 & .10 & .18 \\
\hline \multicolumn{7}{|l|}{ Standard errors in parentheses } \\
\hline$* \mathrm{p}<.05 ; * * \mathrm{p}<.01 ; * * * \mathrm{p}$ & & & & & & \\
\hline
\end{tabular}


Table 3. OLS Results, Change in locus of control from 1999 to 2005

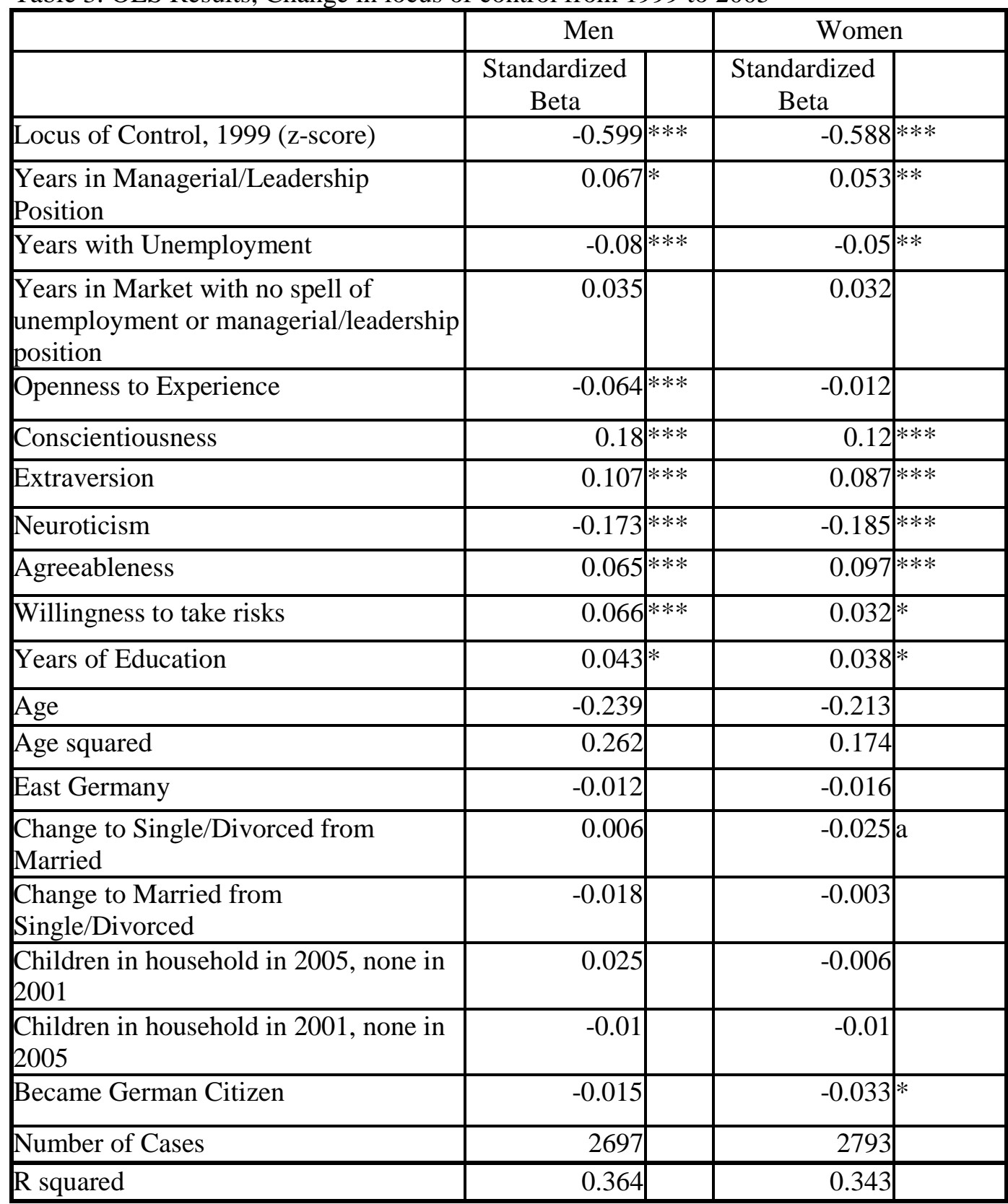

${ }^{*} \mathrm{p}<.05 ;{ }^{* *} \mathrm{p}<.01 ;{ }^{* * *} \mathrm{p}<.001,{ }^{\mathrm{a}} \mathrm{p}<.10$ 


\section{ENDNOTES}

\footnotetext{
${ }^{\text {i }}$ See for example, Lex Borghans, Angela Duckworth, James Heckman, and Bas ter Weel, 2008; Flavio Cunha and James Heckman, 2007; Flavio and Heckman, 2008; Heckman, Jora Stixrud and Sergio Urzua, 2006.

${ }^{\text {ii }}$ Representatives of employers themselves have argued that the promotion of bullying, much of which is identity based, promotes profits. As summarized byYamada (2009):
}

In a sharp criticism of the Healthy Workplace Bill, management-side employment lawyers Timothy Van Dyck and Patricia Mullen closed their commentary by claiming that protections against malicious, harmful mistreatment at work are somehow contrary to high performance expectations for workers and healthy competition. They posited that "tension created by competition" fuels productivity at work, and the Healthy Workplace Bill "would not only inhibit productivity and employers' freedom to hire and fire at will employees but moreover, it would chill critical workplace communication. ... In essence, the authors are claiming that malicious, targeted mistreatment of an employee is all part of healthy competition, a form of social Darwinism that separates the wheat from the chaff and frees people to excel. It never considers the mounting research showing that workplace bullying reduces productivity and employee loyalty and causes workers to engage in "play it safe” behavior. (Yamada, 2009, pp. 1516).

iii The U.S. Chamber of Commerce also filed an amicus curie brief in the 1986 U.S. Supreme Court Meritor Savings Bank v.Vinson, where they argued that a sexually aggressive hostile work environment should not be considered a form of sexual discrimination and should be not actionable. In this case, the Court held that "Title VII coverage was not limited to tangible employment actions, and that Title VII does prohibit sexually hostile work environments (Growe, 2007, p. 283).”

iv Hacker \& Pierson, 2010, provide empirical evidence and a set of well developed arguments on the role of political influence of the business committee and the elite in producing the high salaries earned by financial analysts, bankers, and high level executives in the United States. In their analysis, the authors discuss why workers in the United States are no longer receiving wage gains as a result of productivity increases in the economy as a whole while stagnating real wages have been accompanied by major transfers of income to the top $1 \%$ of the income distribution.

${ }^{v}$ Such an argument could be extended to other changes in fortunes that occurred over the same time period under investigation by Borghans et al. For example, if we take as a tautology that high level executive jobs require high levels of tolerance towards risk (Samuel R. Gray and Albert A. Cannella, Jr. 1997), we could argue from the 1980s to 2011, the mushrooming salaries of U.S. executives (AFL-CIO, 2011) occurred because the United States economy produced jobs that demanded high levels of tolerance towards risk. Between these periods, the salaries of CEOs relative to blue collars workers increased from a ratio of 42 to a ratio of 343 . Other theorists working outside of economics have in fact argued that the causality between risk and wages for high level CEOs sometimes run in the opposite direction: that the high wages for bankers produced excessive risk taking and not the converse (Lucian A. Bebchuk and Holger Spamann. 2010). Neither human capital theory nor identity theory, however, could permit such an alternative explanation.

\footnotetext{
${ }^{\text {vi }}$ See endnote i above and Bowles and Gintis (1976; 2002); Bowles, Gintis, and Osborne (2002)

${ }^{\text {vii }}$ We attempted to estimate a four equation model that included years in market work as one of the endogenous model. This model specification would not converge in either of the two statistical programs that we used to test the model—Stata Version 9 and EQS Version 6.

viii Households with a net monthly income of approx. €4,000 and above.
}

${ }^{\text {ix }}$ For example Anne Busch \& Elke Holst (2009); Holst (2009); Holst \& Schimeta (2009); Holst (2006); Holst et al. (2006). 
${ }^{\mathrm{x}}$ Leaders amongst blue-collar workers (master craftsmen and foremen) were not included in the analysis. An independent analysis of this group is not possible, particularly amongst women, due to the low number of cases.

${ }^{x i}$ Classification took place on the basis of the question "Does the organisation for which you work form part of the civil service?" "Yes" or "No".

xii The question in the SOEP is: "Now a completely different subject: our every-day actions are influenced by our basic belief. There is very limited scientific knowledge available on this topic. Below are different qualities that a person can have. You will probably find that some apply to you perfectly and that some do not apply to you at all. With others, you may be somewhere in between. Please answer according to the following scale: "I see myself as someone who..." The respondents were given 15 adjectives or statements to evaluate on a scale of 1: Does not apply to me at all to up to 7: Applies to me perfectly.

xiii We used standard factor analyses techniques with varimax rotation, standard eigenvalue criteria, total variability explained and visual examination of the scree plots (Craig Mertler and Rachel Vannatta, 2005) 